\title{
Source attribution of black carbon and its direct radiative forcing in China
}

\author{
Yang Yang ${ }^{1}$, Hailong Wang ${ }^{1}$, Steven J. Smith ${ }^{2}$, Po-Lun Ma ${ }^{1}$, and Philip J. Rasch ${ }^{1}$ \\ ${ }^{1}$ Atmospheric Science and Global Change Division, Pacific Northwest National Laboratory, Richland, Washington, USA \\ ${ }^{2}$ Joint Global Change Research Institute, Pacific Northwest National Laboratory, College Park, Maryland, USA
}

Correspondence to: Yang Yang (yang.yang@pnnl.gov) and Hailong Wang (hailong.wang@pnnl.gov)

Received: 18 November 2016 - Discussion started: 29 November 2016

Revised: 23 February 2017 - Accepted: 9 March 2017 - Published: 30 March 2017

\begin{abstract}
The source attributions for mass concentration, haze formation, transport and direct radiative forcing of black carbon (BC) in various regions of China are quantified in this study using the Community Earth System Model (CESM) with a source-tagging technique. Anthropogenic emissions are from the Community Emissions Data System that is newly developed for the Coupled Model Intercomparison Project Phase 6 (CMIP6). Over north China where the air quality is often poor, about $90 \%$ of near-surface $\mathrm{BC}$ concentration is contributed by local emissions. Overall, $35 \%$ of $\mathrm{BC}$ concentration over south China in winter can be attributed to emissions from north China, and $19 \%$ comes from sources outside China in spring. For other regions in China, BC is largely contributed from nonlocal sources. We further investigated potential factors that contribute to the poor air quality in China. During polluted days, a net inflow of BC transported from nonlocal source regions associated with anomalous winds plays an important role in increasing local $\mathrm{BC}$ concentrations. BC-containing particles emitted from East Asia can also be transported across the Pacific. Our model results show that emissions from inside and outside China are equally important for the $\mathrm{BC}$ outflow from East Asia, while emissions from China account for $8 \%$ of $\mathrm{BC}$ concentration and $29 \%$ in column burden in the western United States in spring. Radiative forcing estimates show that $65 \%$ of the annual mean $\mathrm{BC}$ direct radiative forcing $\left(2.2 \mathrm{~W} \mathrm{~m}^{-2}\right)$ in China results from local emissions, and the remaining $35 \%$ is contributed by emissions outside of China. Efficiency analysis shows that a reduction in $\mathrm{BC}$ emissions over eastern China could have a greater benefit for the regional air quality in China, especially in the winter haze season.
\end{abstract}

\section{Introduction}

Black carbon (BC), as a component of atmospheric fine particulate matter $\left(\mathrm{PM}_{2.5}\right)$, is harmful to human health (Anenberg et al., 2011; Janssen et al., 2012). In addition to its impact on air quality, as the most efficient light-absorbing anthropogenic aerosols, $\mathrm{BC}$ is thought to exert a substantial influence on climate (Bond et al., 2013; IPCC, 2013; Liao et al., 2015). It can heat the atmosphere through absorbing solar radiation (Ramanathan and Carmichael, 2008), influence cloud microphysical and dynamical processes (Jacobson, 2006; McFarquhar and Wang, 2006), and reduce surface albedo through deposition on snow and ice (Flanner et al., 2007; Qian et al., 2015).

Due to accelerated urbanization and rapid economic growth, emissions of BC in China have increased dramatically during recent decades. It contributed to about one fourth of the global emissions of BC in recent decades (Bond et al., 2007). Strong emissions lead to high concentrations of BC over China. Zhang et al. (2008) collected aerosol samples at 18 stations spread over China during 2006 and reported $\mathrm{BC}$ concentrations in a range of $9-14 \mu \mathrm{g} \mathrm{m}^{-3}$ at urban sites, $2-5 \mu \mathrm{g} \mathrm{m}^{-3}$ at rural sites and about $0.35 \mu \mathrm{g} \mathrm{m}^{-3}$ at remote background sites. BC also exerts significant positive direct radiative forcing (DRF) at the top of the atmosphere (TOA) in China. Using the Regional Climate Chemistry Modeling System (RegCCMs), Zhuang et al. (2013) reported an annual mean BC DRF of $2-5 \mathrm{~W} \mathrm{~m}^{-2}$ at TOA over eastern China and about $6 \mathrm{~W} \mathrm{~m}^{-2}$ over the Sichuan Basin in 2006. Li et al. (2016) also showed a strong DRF of BC over the North China Plain and the Sichuan Basin in most seasons except for spring when the strongest BC DRF with values of 4$6 \mathrm{~W} \mathrm{~m}^{-2}$ shifted to southern China. 
$\mathrm{BC}$ is the product of incomplete combustion of fossil fuels, biofuels and open burning, such as forest and grassland fires and agricultural waste burning on fields. In the atmosphere the average lifetime of BC is only a few days, due to both wet removal and dry deposition, which is much shorter than that of long-lived greenhouse gases. In addition, BC lifetime is region dependent. $\mathrm{BC}$ in East Asia has a shorter lifetime than the global mean value due to a faster regional removal $(\mathrm{H}$. Wang et al., 2014), probably associated with strong precipitation during the monsoon season. $\mathrm{BC}$ emission reductions may benefit both the mitigation of global climate change and regional air quality (Shindell et al., 2012; Bond et al., 2013; Smith and Mizrahi, 2013), especially in East Asia where fuel combustion emits substantial BC along with other pollutant species. Many previous observational and/or modeling studies have examined the source sector contributions of $\mathrm{BC}$ over China (Zhuang et al., 2014; Y.-L. Zhang et al., 2015; Li et al., 2016). They found that the residential heating and industry sectors were the largest contributors to $\mathrm{BC}$ concentrations in China, while biomass burning emissions from outside China were important to $\mathrm{BC}$ in western China. An effective $\mathrm{BC}$ reduction in a receptor region would require knowing not only the source sector that contributes the most to BC levels, but also the source contributions from various locations within and outside the region. However, very few previous studies have focused on the source attribution of $\mathrm{BC}$ concentrations in various regions of China. Li et al. (2016) examined the contributions of emissions inside and outside China to BC over China (with only two source regions) but did not divide the source contributions from different regions inside China.

Pollution levels also show substantial daily to weekly variation. In recent years, extreme wintertime hazy conditions occurred frequently in China and caused serious air pollution, affecting more than half of the 1.3 billion people (Ding and Liu, 2014). During one winter haze episode in 2013, BC concentrations increased up to about 20 and $8 \mu \mathrm{g} \mathrm{m}^{-3}$ over northern China in Xi' an and Beijing, and 6 and $4 \mu \mathrm{g} \mathrm{m}^{-3}$ over southern China in Guangzhou and Shanghai, respectively (Y.-L. Zhang et al., 2015). The transport of pollutants from upwind was reported to be one of the most important contributors to local high aerosol concentrations during haze days (L. T. Wang et al., 2014; Y. Yang et al., 2016). L. T. Wang et al. (2014) found that emissions from northern Hebei and Beijing-Tianjin were the major contributor to particulate matter $\left(\mathrm{PM}_{2.5}\right)$ pollution in Shijiazhuang in January 2013. Yang et al. (2016) confirmed a connection between wind fields and $\mathrm{PM}_{2.5}$ concentrations during winter hazy days through model simulations and statistical analysis. They also found that weakened winds contributed to increases in winter aerosol concentrations and hazy days over eastern China during recent decades. As a chemically inert species, atmospheric BC is a good tracer to investigate the source region contributions from local and nonlocal emissions during polluted conditions that are related to long-range transport.
BC particles originating from East Asia can also be transported across the North Pacific, reaching North America (Hadley et al., 2007; Ma et al., 2013a; Matsui et al., 2013; H. Wang et al., 2014; Yang et al., 2015). Matsui et al. (2013) simulated outflow of BC from East Asia using the Community Multiscale Air Quality (CMAQ) model and found that anthropogenic emissions from China, biomass burning emissions from Southeast Asia, and biomass burning emissions from Siberia and Kazakhstan contributed 61, 17 and $6 \%$, respectively, to the eastward $\mathrm{BC}$ flux at $150^{\circ} \mathrm{E}$ averaged over 2008-2010. Hadley et al. (2007) estimated the trans-Pacific transport of BC during April of 2004 using the Chemical Weather Forecast System (CFORS) model and reported that, across $130^{\circ} \mathrm{W}, 75 \%$ of $\mathrm{BC}$ transported into North America originated from Asia. Huang et al. (2013) simulated BC using the Sulfur Transport and Deposition Model (STEM) and found that emissions outside North America contributed 30$80 \%$ of column BC over North America in summer 2008. H. Wang et al. (2014) examined the long-term (1995-2005) average global source-receptor relationship of $\mathrm{BC}$ and found that $\mathrm{BC}$ emitted from all of East Asia only contributes less than $5 \%$ to the total $\mathrm{BC}$ burden in North America, although the contribution is up to $40 \%$ near the west coast region. Few studies have examined the outflow from East Asia and inflow into North America from source regions in and outside China. In addition, the emissions of $\mathrm{BC}$ from China have increased dramatically during the last few years, with the annual total anthropogenic emissions estimated to have almost doubled in 2014 compared to 2000, as shown in the newly developed Community Emissions Data System (CEDS; Hoesly et al., 2017). Therefore, the long-range transport of BC and source-receptor relationships could be quite different from previous studies.

Due to its warming effect in the climate system, $\mathrm{BC}$ is potentially important for climate mitigation and has attracted much attention recently. The source attribution of the direct radiative effect of $\mathrm{BC}$ is likely to be different from that of the near-surface concentration and column burden due to the dependence of radiative forcing on the vertical distribution of $\mathrm{BC}$ and its mixing state with other species that are influenced by different regional sources. In this study, we use the Community Earth System Model (CESM) with improved representations of aerosol transport and wet removal (H. Wang et al., 2013) and a BC source-tagging technique (H. Wang et al., 2014). Anthropogenic emissions from the newly developed CEDS inventory (Hoesly et al., 2017), as released for the Coupled Model Intercomparison Project Phase 6 (CMIP6), are used to examine the source attributions for mass concentration, long-range transport and direct radiative forcing of $\mathrm{BC}$ in various regions of China. We aim to quantify (1) source region contributions to concentrations of $\mathrm{BC}$ over various receptor regions in China; (2) contributions to changes in $\mathrm{BC}$ concentrations under polluted conditions; (3) source contributions to trans-boundary and trans-Pacific 
transport of $\mathrm{BC}$; and (4) source contributions to direct radiative forcing of $\mathrm{BC}$ in China.

The CESM model, emissions and numerical experiment are described in Sect. 2. Section 3 provides evaluation of the simulated concentration and aerosol absorption optical depth of BC in China. Section 4 investigates source contributions to near-surface concentrations, long-range transport and direct radiative forcing of $\mathrm{BC}$ over various receptor regions using the $\mathrm{BC}$ source-tagging technique in CESM. Section 5 summarizes these results.

\section{Methods}

We simulate the evolution and direct radiative forcing (DRF) of BC using CESM version 1.2 (Hurrell et al., 2013). The atmospheric model in CESM is version 5 of the Community Atmosphere Model (CAM5), with horizontal grid spacing of $1.9^{\circ}$ latitude by $2.5^{\circ}$ longitude and 30 vertical layers ranging from the surface to $3.6 \mathrm{hPa}$ used in this study. The model treats the properties and processes of major aerosol species (sea salt, mineral dust, sulfate, black carbon, primary organic matter and secondary organic aerosol) using a three-mode modal aerosol module (MAM3), in which aerosol size distributions are represented by three lognormal modes: Aitken, accumulation and coarse modes. BC is emitted to the accumulation mode. Mass mixing ratios of different aerosol species and the number mixing ratio are predicted for each mode. A more detailed description of the MAM3 representation can be found in Liu et al. (2012). Aerosol dry deposition velocities are calculated using the Zhang et al. (2001) parameterization. The wet deposition of aerosols in our CAM5 model includes in-cloud wet removal (i.e., activation of interstitial aerosols to cloud-borne particles followed by precipitation scavenging) and below-cloud wet removal (i.e., capture of interstitial aerosol particles by falling precipitation particles) for both stratiform and convective clouds. Aerosol activation is calculated with the parameterization of AbdulRazzak and Ghan (2000) for stratiform cloud throughout the column and convective cloud at cloud base, while the secondary activation above the convective cloud base has a simpler treatment with an assumed maximum supersaturation in convective updrafts (H. Wang et al., 2013). The unified treatment for convective transport and aerosol wet removal along with the explicit aerosol activation above convective cloud base were developed by $\mathrm{H}$. Wang et al. (2013) and included in the CAM5 version being used in this study. This implementation reduces the excessive $\mathrm{BC}$ aloft and better simulates observed BC concentrations in the mid- to upper troposphere. Aerosol optical properties for each mode are parameterized according to Ghan and Zaveri (2007). Refractive indices for aerosols are taken from the OPAC (optical properties for aerosols and clouds) software package (Koepke and Schult, 1998), but for BC at solar wavelengths the values are updated from Bond and Bergstrom (2006). In MAM3, the aging process of $\mathrm{BC}$ is neglected by assuming the immediate mixing of $\mathrm{BC}$ with other aerosol species. Direct radiative forcing of $\mathrm{BC}$ is calculated as the difference in the top-ofthe-atmosphere net radiative fluxes with and without $\mathrm{BC}$ for the all-sky condition following Ghan (2013).

Anthropogenic emissions used in this study are from the CEDS dataset, as released for the CMIP6 model experiments (Hoesly et al., 2017). This newly released emission inventory includes aerosol (black carbon, organic carbon) and aerosol precursor and reactive compounds (sulfur dioxide, nitrogen oxides, ammonia, carbon monoxide and non-methane volatile organic compounds). The emissions are provided at monthly resolution for each year of 1750-2014 on a $0.5^{\circ} \times 0.5^{\circ}$ grid and include agricultural, energy, industry, residential, international shipping, solvents, surface transportation, waste treatment and aircraft sectors. The biomass burning emissions used in this study are also developed for CMIP6 based on Global Fire Emission Database (GFED) version 4, Fire Model Intercomparison Project (FireMIP), visibility observations and Global Charcoal Database (GCD) data (van Marle et al., 2017).

Figure 1a shows the horizontal spatial distribution of annual emissions of BC averaged over the most recent 5 years (2010-2014) and the seven geographical source regions tagged in continental China, including north China (NC), south China (SC), southwest China (SW), central-west China (CW), northeast China (NE), northwest China (NW) and the Tibetan Plateau (TP). Figure 1b summarizes the total seasonal $\mathrm{BC}$ emissions in each of these source regions. North China has the largest annual emissions of BC in China, with a maximum emission larger than $1.2 \mathrm{~g} \mathrm{C} \mathrm{m}^{-2} \mathrm{yr}^{-1}$ and a regional total emission of $1089 \mathrm{Gg} \mathrm{C} \mathrm{yr}^{-1}$ (44\% of total emissions from continental China). Annual emissions of BC also have large values over south and southwest China, with maximum values in the range of $0.8-1.2 \mathrm{~g} \mathrm{C} \mathrm{m}^{-2} \mathrm{yr}^{-1}$, followed by central-west and northeast China. Over the less economically developed northwest of China and the remote region of the Tibetan Plateau, emissions of $\mathrm{BC}$ are much lower than other regions in China. The seasonal mean emissions of BC also show the same spatial pattern as the annual means. BC had the largest emissions over north, south and southwest China in all seasons, among which emissions are strongest in December-January-February (DJF), especially over north China, resulting from domestic heating. The total seasonal emissions of BC in continental China are 797, 586, 537 and 577 Gg C in DJF, March-April-May (MAM), June-July-August (JJA) and September-OctoberNovember (SON), respectively, which add up to a total annual BC emissions of $2497 \mathrm{Gg} \mathrm{C}$ averaged over 2010-2014. The anthropogenic emissions of BC in China in 2010-2014 are larger than those used in the previous studies for earlier years (Table S1 in the Supplement), partly as a result of a higher estimate of $\mathrm{BC}$ emissions from coal coking production. The higher emissions likely lead to higher concentrations and direct radiative forcing and source contributions of 

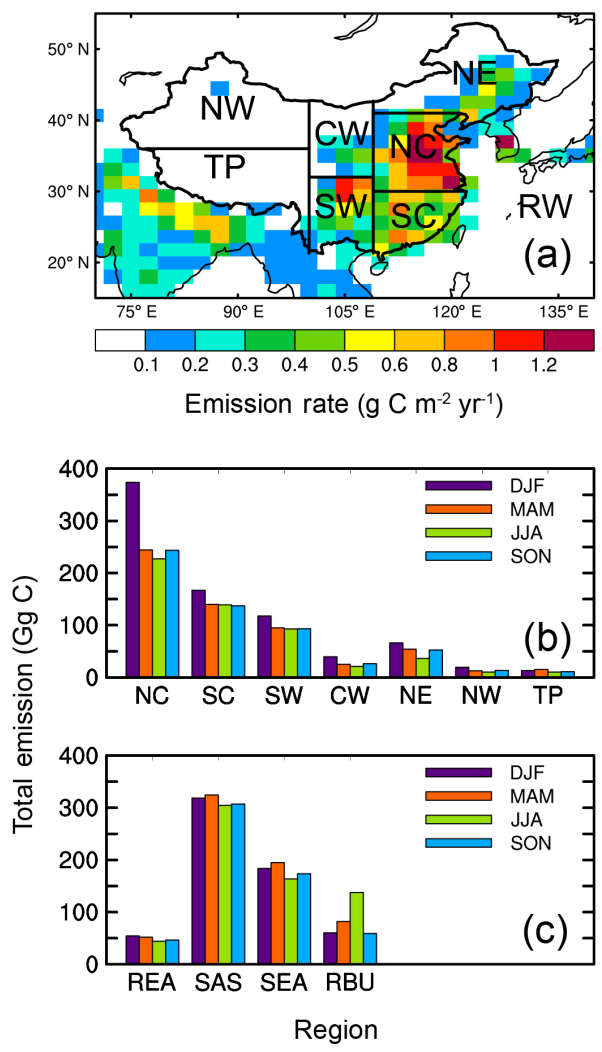

Figure 1. (a) Spatial distribution of annual mean total emissions (anthropogenic plus biomass burning in units of $\mathrm{g} \mathrm{C} \mathrm{m}^{-2} \mathrm{yr}^{-1}$ ) of black carbon (BC) averaged over 2010-2014. The geographical BC source regions are selected as north China (NC; $109^{\circ} \mathrm{E}$-east border, 30-41 ${ }^{\circ} \mathrm{N}$ ), south China (SC; $109^{\circ} \mathrm{E}$-east border, south border$\left.30^{\circ} \mathrm{N}\right)$, southwest China ( $\mathrm{SW} ; 100-109^{\circ} \mathrm{N}$, south border $\left.-32^{\circ} \mathrm{N}\right)$, central-west China $\left(\mathrm{CW} ; 100,-109^{\circ} \mathrm{N}, 32^{\circ} \mathrm{N}\right.$-north border), northeast China (NE; $109^{\circ} \mathrm{E}$-east border, $41^{\circ} \mathrm{N}$-north border), northwest China (NW; west border- $100^{\circ} \mathrm{E}, 36^{\circ} \mathrm{N}$-north border) and the Tibetan Plateau (TP; west border $-100^{\circ} \mathrm{E}$, south border $-36^{\circ} \mathrm{N}$ ) in China and regions outside of China (RW; rest of the world). (b) Seasonal mean total emissions (units: $\mathrm{Gg} \mathrm{C} ; \mathrm{Gg}: 10^{9} \mathrm{~g}$ ) of $\mathrm{BC}$ from the seven BC source regions in China and emissions from the rest of East Asia (REA, with China excluded), South Asia (SAS), Southeast Asia (SEA) and Russia-Belarussia-Ukraine (RBU).

BC in China, compared to the values reported in these studies. The DJF emissions account for $26-35 \%$ of the annual total, whereas emissions in JJA only account for $17-24 \%$ over the seven source regions in continental China. Total BC emissions from neighboring regions including the rest of East Asia (REA, with China excluded), South Asia (SAS), Southeast Asia (SEA) and Russia-Belarussia-Ukraine (RBU) are shown in Fig. 1c. These source regions outside China are consistent with source regions defined in the second phase of Hemispheric Transport of Air Pollution (HTAP2). South Asia and Southeast Asia have relatively high emissions. They may dominate the contribution to concentrations and direct radiative forcing of $\mathrm{BC}$ in China, especially southern and western China, from foreign sources through long-range transport.

An explicit BC source-tagging capability was originally implemented in CAM5 by H. Wang et al. (2014), through which emissions of $\mathrm{BC}$ from independent source regions and/or sectors can be explicitly tracked. This method quantifies the source-receptor relationships of BC in any receptor region within a single model simulation without perturbing emissions from individual source regions or sectors. R. Zhang et al. (2015a, b) used this method to quantify the source attributions of $\mathrm{BC}$ in western North America, the Himalayas and the Tibetan Plateau. The same BC sourcetagging technique is implemented to a newer model version (CAM5.3) and applied in this study to quantify the source attributions of concentration, transport and direct radiative forcing of $\mathrm{BC}$ in various regions of China. BC emissions (anthropogenic plus biomass burning) from seven geographical source regions, including north China, south China, southwest China, central-west China, northeast China, northwest China, the Tibetan Plateau in China and from the rest of the world (RW) are tagged. Transport and physics tendencies are calculated separately for each tagged BC in the same way as the original BC simulation in CESM. We choose the seven individual regions (north China, south China, southwest China, central-west China, northeast China, northwest China and the Tibetan Plateau) and all seven regions combined (hereafter continental China) as receptor regions in this study to examine the source-receptor relationships of BC. While all emissions, including sulfur dioxides, organic carbon and $\mathrm{BC}$, were used in the model simulation, tagging was only applied to $\mathrm{BC}$ emissions.

The CAM5 simulation is performed at $1.9^{\circ} \times 2.5^{\circ}$ horizontal grid spacing using the specifieddynamics mode (Ma et al., 2013b), in which large-scale circulations (i.e., horizontal winds) are nudged to 6-hourly reanalysis data from the Modern Era Retrospective-Analysis for Research and Applications (MERRA) reanalysis data set (Rienecker et al., 2011) with a relaxation timescale of $6 \mathrm{~h}$ (K. Zhang et al., 2014). The use of nudged winds allows for a more accurate simulation so that the key role of large-scale circulation patterns matches observations over the specified years. The simulation is run from 2009 to 2014, with both time-varying aerosol emissions and meteorological fields. The first year is for spin-up and the last 5 years are used for analysis.

\section{Model evaluation}

The simulations of aerosols, especially BC, using CAM5 have been extensively evaluated against observations including aerosol mass and number concentrations, vertical profiles, aerosol optical properties, aerosol deposition and cloudnucleating properties in several previous studies (e.g., Liu et al., 2012, 2016; H. Wang et al., 2013; Ma et al., 2013b; Jiao et 

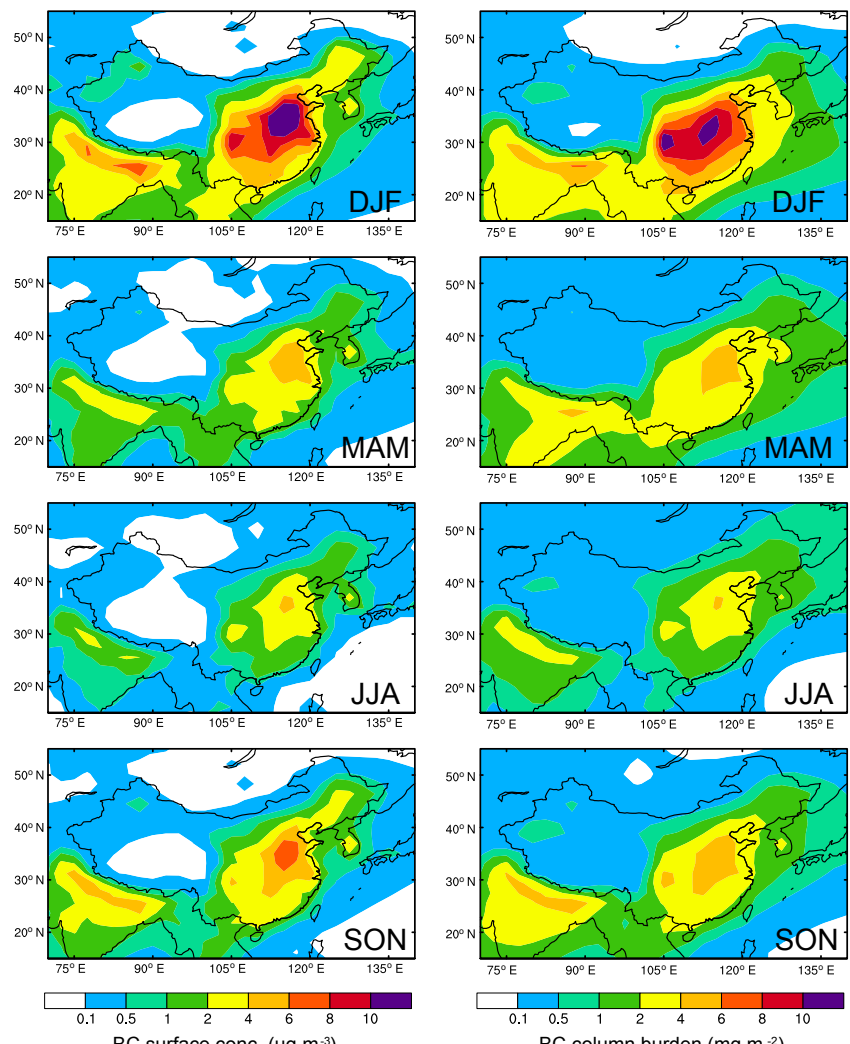

Figure 2. Simulated seasonal mean near-surface concentrations (left; units: $\mu \mathrm{g} \mathrm{m}^{-3}$ ) and column burden (right; units: $\mathrm{mg} \mathrm{m}^{-2}$ ) of BC in December-January-February (DJF), March-AprilMay (MAM), June-July-August (JJA) and September-OctoberNovember (SON).

al., 2014; Qian et al., 2014; R. Zhang et al., 2015a, b). Here we focus on the evaluation of model performance in China using measurements of near-surface $\mathrm{BC}$ concentrations, vertical profiles, aerosol index derived from satellites and the aerosol absorption optical depth from the Aerosol Robotic Network (AERONET).

\subsection{Mass concentrations and column burden of BC}

Figure 2 presents spatial distributions of simulated seasonal mean near-surface concentrations and column burden of BC, both of which show a similar spatial pattern to emissions of BC (Fig. 1a), with the largest values over north China and the lowest values over northwest China and the Tibetan Plateau. Near-surface model results are taken to be the lowest model layer (from surface to $985 \mathrm{hPa}$ in average). Among all seasons, DJF has the highest $\mathrm{BC}$ levels, with values in the range of 6-12, 2-8 and $1-8 \mu \mathrm{g} \mathrm{m}^{-3}$ for near-surface concentrations and $6-12,2-8$ and $1-12 \mathrm{mg} \mathrm{m}^{-2}$ for the column burden over north, south and southwest China, respectively. In contrast, JJA has the lowest $\mathrm{BC}$ concentrations over China due to the lower emissions and larger wet scavenging associated with the East Asian summer monsoon (Lou et al., 2016). Averaged over continental China, near-surface $\mathrm{BC}$ concentrations are 2.5, 1.1, 0.8 and $1.4 \mathrm{\mu g} \mathrm{m}^{-3}$ in DJF, MAM, JJA and SON, respectively, with a seasonal variability of $50 \%$. The column burden of BC shows smaller seasonal variability (40\%), with an area-weighted average of $2.5,1.4,1.0$ and $1.4 \mathrm{mg} \mathrm{m}^{-2}$ in DJF, MAM, JJA and SON, respectively, in China. The magnitude, spatial distribution and seasonal variations of simulated near-surface BC concentrations over China are similar to those in Fu et al. (2012) and X. Wang et al. (2013) using the Intercontinental Chemical Transport ExperimentPhase B (INTEX-B) emission inventory (Zhang et al., 2009) and those in Li et al. (2016) using the HTAP emission inventory (Janssens-Maenhout et al., 2015) together with a global chemical transport model.

The simulated near-surface $\mathrm{BC}$ concentrations are evaluated here using measurements at 14 sites of the China Meteorological Administration Atmosphere Watch Network (CAWNET) (Zhang et al., 2012). The locations of CAWNET sites are shown in Fig. S1a in the Supplement. The observational data include monthly BC concentrations in 20062007. Note that the simulated BC concentrations are for 2010-2014. Figure 3a compares the simulated seasonal mean near-surface BC concentrations with those from CAWNET observations, and Table S2 summarizes the comparison in different regions, using modeled values from the grid cell containing each observational site. Simulated BC concentrations at most sites are within the range of one third to 3 times the observed values, except over western China at the Dunhuang $\left(94.68^{\circ} \mathrm{E}, 40.15^{\circ} \mathrm{N}\right)$ and Lhasa $\left(91.13^{\circ} \mathrm{E}, 29.67^{\circ} \mathrm{N}\right)$ sites, where $\mathrm{BC}$ concentrations appear to be underestimated in the model (up to 20 times lower). The possible bias is discussed in the following part. Over north China, simulated concentrations are similar to observations in DJF but are underestimated in other seasons. Over south China, the simulations do not have large biases compared to the observed BC. However, simulated BC is underestimated in all seasons over southwest, central-west, northeast and northwest China and the Tibetan Plateau. Compared to the CAWNET data, the modeled near-surface BC concentrations have a normalized mean bias (NMB) of $-48 \%$. Note that anthropogenic $\mathrm{BC}$ emissions went up by a factor of 1.18 between 2006-2007 and 2010-2014. An emissions-adjusted comparison would result in an even larger underestimation. There are several reasons that might cause low bias in this comparison. Liu et al. (2012) and H. Wang et al. (2013) have previously found an underestimation of $\mathrm{BC}$ concentrations over China in the CAM5 model and suggested that the BC emissions may be significantly underestimated. Using the global chemical transport model GEOS-Chem together with emissions in 2006, Fu et al. (2012) found that the simulated BC concentrations in China were underestimated by $56 \%$. With HTAP emissions at the level of 2010, Li et al. (2016) showed a low bias of $37 \%$ in simulated BC concentration in China. A larger wet removal rate and shorter lifetime of aerosols 

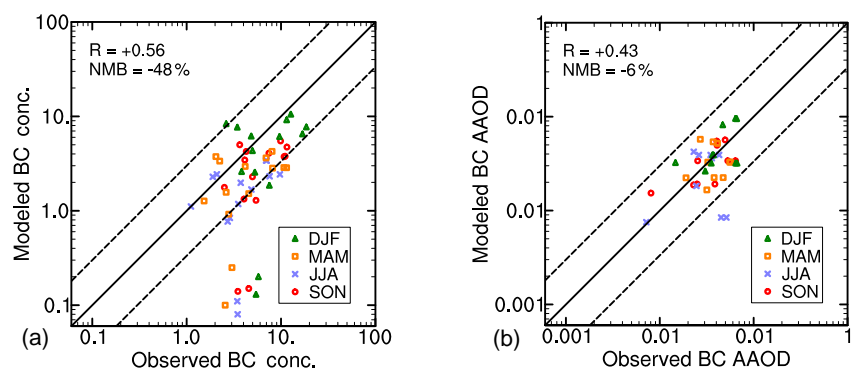

Figure 3. Comparisons of observed and modeled seasonal mean (a) near-surface concentrations (units: $\mu \mathrm{g} \mathrm{m}^{-3}$ ) and (b) aerosol absorption optical depth (AAOD) of BC in China. Solid lines mark the $1: 1$ ratios, and dashed lines mark the $1: 3$ and $3: 1$ ratios. Observed BC concentrations were taken between 2006 and 2007 at 14 sites of the China Meteorological Administration (CMA) Atmosphere Watch Network (CAWNET) (Zhang et al., 2012). Observed AAOD of BC is obtained by removing dust AAOD from total AAOD at 10 sites of the Aerosol Robotic Network (AERONET) (Holben et al., 2001), following Bond et al. (2013). The observed AAOD are averaged over 2005-2014 where data are available. Correlation coefficient $(R)$ and normalized mean bias (NMB) between observation and simulation are shown at the top left of each panel. $\mathrm{NMB}=100 \% \times \sum\left(M_{i}-O_{i}\right) / \sum O_{i}$, where $M_{i}$ and $O_{i}$ are the modeled and observed values at site $i$, respectively. Site locations are shown in Fig. S1a.

along with the instantaneous aging of BC in the MAM3 can also lead to the lower concentrations of BC (e.g., Wang et al., 2011; Liu et al., 2012; H. Wang et al., 2013; Kristiansen et al., 2016).

Another potential cause of a bias in this comparison is spatial sampling bias. Half of the CAWNET sites are located in urban areas, which will tend to have high values near sources, whereas the modeled values represent averages over large grid cells (R. Wang et al., 2014), as further discussed below.

The model captures the spatial distribution and seasonal variation of $\mathrm{BC}$ concentrations in China well, having a statistically significant correlation coefficient of +0.56 between simulated and observed seasonal BC concentrations over CAWNET sites.

Figure S2 compares the observed and simulated vertical profiles of BC concentrations in the East Asian outflow region. The model successfully reproduces the vertical profile of BC that was measured in March-April 2009 during the A-FORCE field campaign, reported by Oshima et al. (2012).

\subsection{Aerosol absorption optical depth of BC}

To evaluate the simulated aerosol absorption optical depth (AAOD) of BC, the AAOD data from AERONET (Holben et al., 2001) are used here. The locations of AERONET sites in China are shown in Fig. S1b. The observed AAOD are averaged over 2010-2014 over seven sites and 2005-2010 over three sites where data are available. Most AERONET sites are over eastern and central China. AAOD of BC at $550 \mathrm{~nm}$ is calculated by interpolating AAOD at 440 and $675 \mathrm{~nm}$ and removing AAOD of dust from the retrieved AERONET AAOD following Bond et al. (2013). Figure 3b compares the observed and simulated seasonal mean AAOD of BC at $550 \mathrm{~nm}$, and Table S3 summarizes the comparisons in different regions. The model has a low bias in simulating AAOD of $\mathrm{BC}$ in China, smaller than the bias in near-surface concentrations, with an NMB of $-6 \%$. As is the case with surface concentrations, this bias could be due to model issues, such as BC transport or optical parameterization, an underestimate in emissions, or spatial sampling bias. Simulated AAOD of $\mathrm{BC}$ is within the range of one third to 3 times the observed values at most sites, with the spatial distribution and seasonal variation broadly captured by the model. All but one of the observations are located in the north and south China regions, and simulated $\mathrm{BC} \mathrm{AAOD}$ is, on average, similar to observations there. The AAOD from one observation site in central-west China is higher than the modeled value in DJF and lower in other seasons. Note that the observed AAOD of $\mathrm{BC}$ is derived from AERONET measurements using the absorption Ångström exponent. A recent study (Schuster et al., 2016) reported that the absorption Angström exponent is not a robust parameter for separating out carbonaceous absorption in the AERONET database, which could cause biases in the AAOD estimates.

Figure 4 shows the spatial distribution of simulated seasonal mean AAOD of total aerosols and the aerosol index (AI) derived from Ozone Monitoring Instrument (OMI) measurements over 2010-2014. AI is a measure of absorbing aerosols, including BC and dust. Compared to satellite AI data, the model roughly reproduces spatial distribution of total AAOD in China, with large values over north, south and southwest China in all seasons. AI derived from Total Ozone Mapping Spectrometer (TOMS) measurements (Fig. S3) also shows similar pattern to simulated AAOD. It should be noted that, besides BC, dust particles also largely contribute to AI and produces large AI values over northwest China.

To examine the potential model bias more broadly we compared the difference in AAOD and AI between western and eastern China (Fig. 4). Averaging AI and AAOD broadly over eastern and western China, we find that the ratio of AAOD and AI is 0.055 over eastern China and 0.027 over western China. If we assume that the simulated AAOD does not have large biases over eastern China based on the evaluation against observations shown above (Fig. 3b and Table S3), then this difference suggests a possible underestimation of BC column burden in the model over the western regions. However, it is difficult to draw a firm conclusion, given the likely differential role of dust in eastern vs. western China. This differential likely also contributes to AAOD biases in modeling dust and may also impact biases in the satellite-derived AI values. 

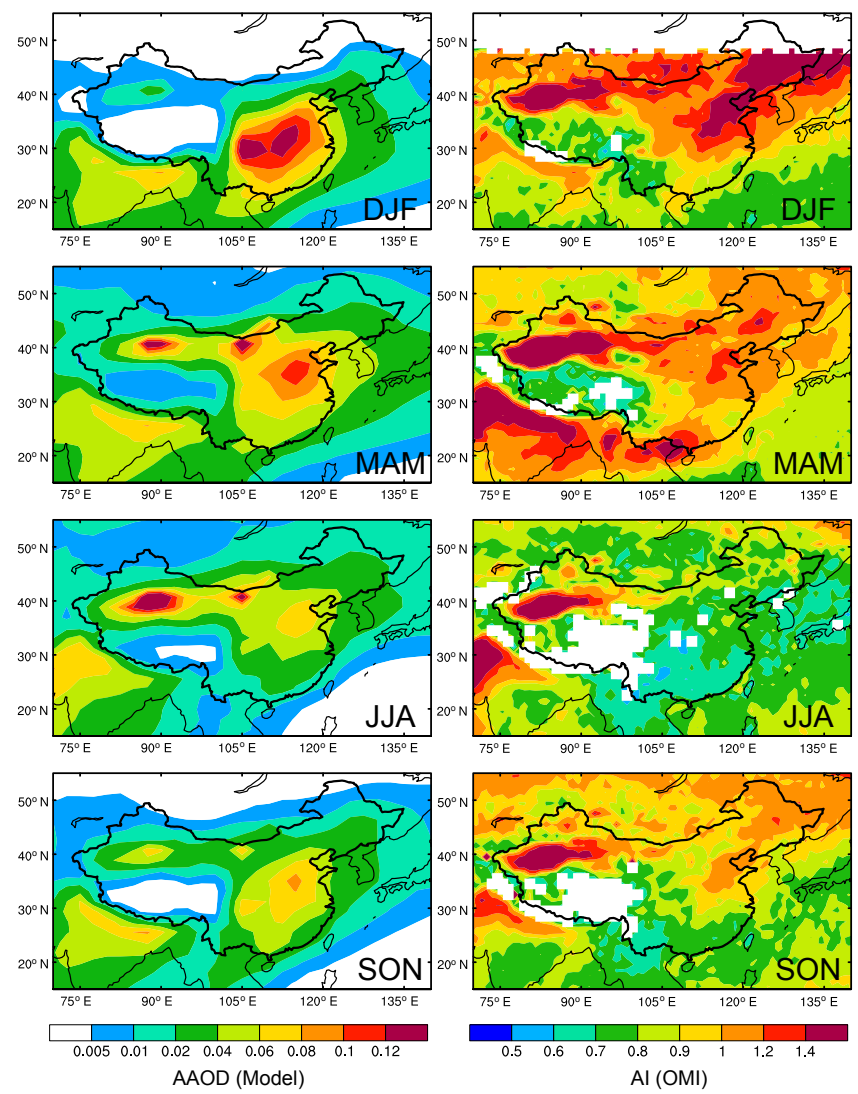

Figure 4. Spatial distribution of seasonal mean AAOD of total aerosols (left) and aerosol index (AI) derived from Ozone Monitoring Instrument (OMI) measurements over 2010-2014 (right).

\section{Source contributions to $\mathrm{BC}$ concentrations, transport and direct radiative forcing}

\subsection{Source contributions to seasonal mean BC concentrations}

Figure 5 shows the simulated spatial distribution of seasonal near-surface $\mathrm{BC}$ concentrations originating from the seven tagged source regions in continental China and all other sources from outside China (rest of the world, RW) and Table S4 summarizes these source-receptor relationships. It is not surprising that regional emissions largely influence BC concentrations in the same region. For example, emissions of $\mathrm{BC}$ from north China give $6.3 \mu \mathrm{g} \mathrm{m}^{-3}$ of $\mathrm{BC}$ concentrations over north China in DJF, whereas they only account for less than $1.8 \mu \mathrm{g} \mathrm{m}^{-3}$ over other regions in China. However, the relatively small amount of BC from upwind source regions can also be a large contributor to receptor regions near the strong sources. BC emissions from north China contribute a large amount to concentrations over south, southwest, central-west and northeast China. BC emissions from south and southwest China also produce a widespread impact on $\mathrm{BC}$ over other neighboring regions. The impacts of

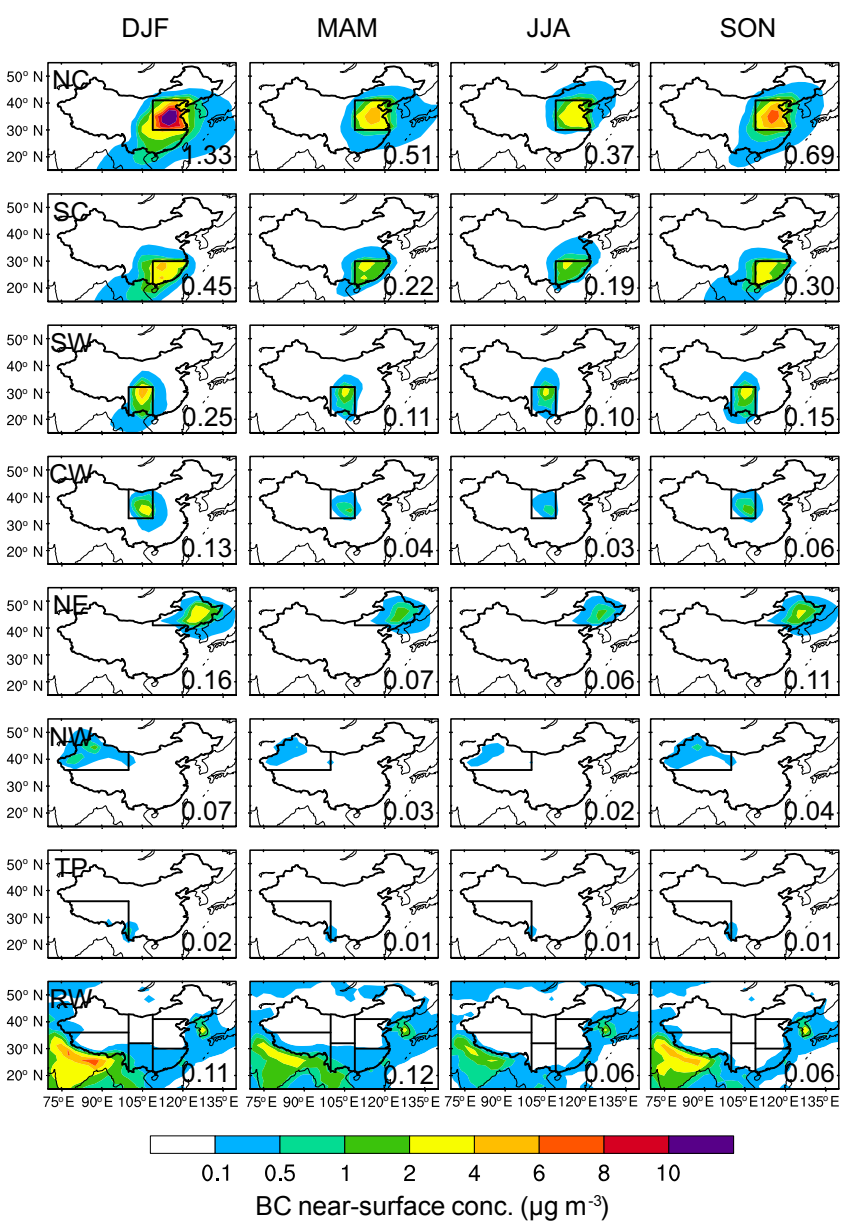

Figure 5. Spatial distribution of seasonal mean near-surface concentrations of $\mathrm{BC}\left(\mu \mathrm{g} \mathrm{m}^{-3}\right)$ originating from the seven source regions in China (NC, SC, SW, CW, NE, NW and TP), marked with black outlines, and sources outside China (RW). Regionally averaged BC in China contributed by individual source regions is shown at the bottom right of each panel.

$\mathrm{BC}$ emitted from the remaining China regions are relatively small both in local and nonlocal regions due to weak emissions (Fig. 1b). All the sources in China have the largest impact in DJF, resulting from the strong $\mathrm{BC}$ emissions in winter, while emissions from outside China have the largest impact on BC over China in MAM due to the seasonal high emission over South and Southeast Asia and the strong springtime southwesterly winds.

Averaged over continental China, emissions of $\mathrm{BC}$ from north China produce mean $\mathrm{BC}$ concentrations of 0.4 $1.3 \mu \mathrm{g} \mathrm{m}^{-3}$, followed by $0.2-0.5 \mu \mathrm{g} \mathrm{m}^{-3}$ from south China and $0.1-0.3 \mu \mathrm{g} \mathrm{m}^{-3}$ from southwest China emissions. For emissions over central-west China, northeast China, northwest China and the Tibetan Plateau, their individual impact is less than $0.2 \mu \mathrm{g} \mathrm{m}^{-3}$. In contrast, emissions from outside China result in $0.12 \mu \mathrm{g} \mathrm{m}^{-3}$ of $\mathrm{BC}$ concentrations in China in MAM and less than $0.06 \mu \mathrm{g} \mathrm{m}^{-3}$ in JJA and SON. The 


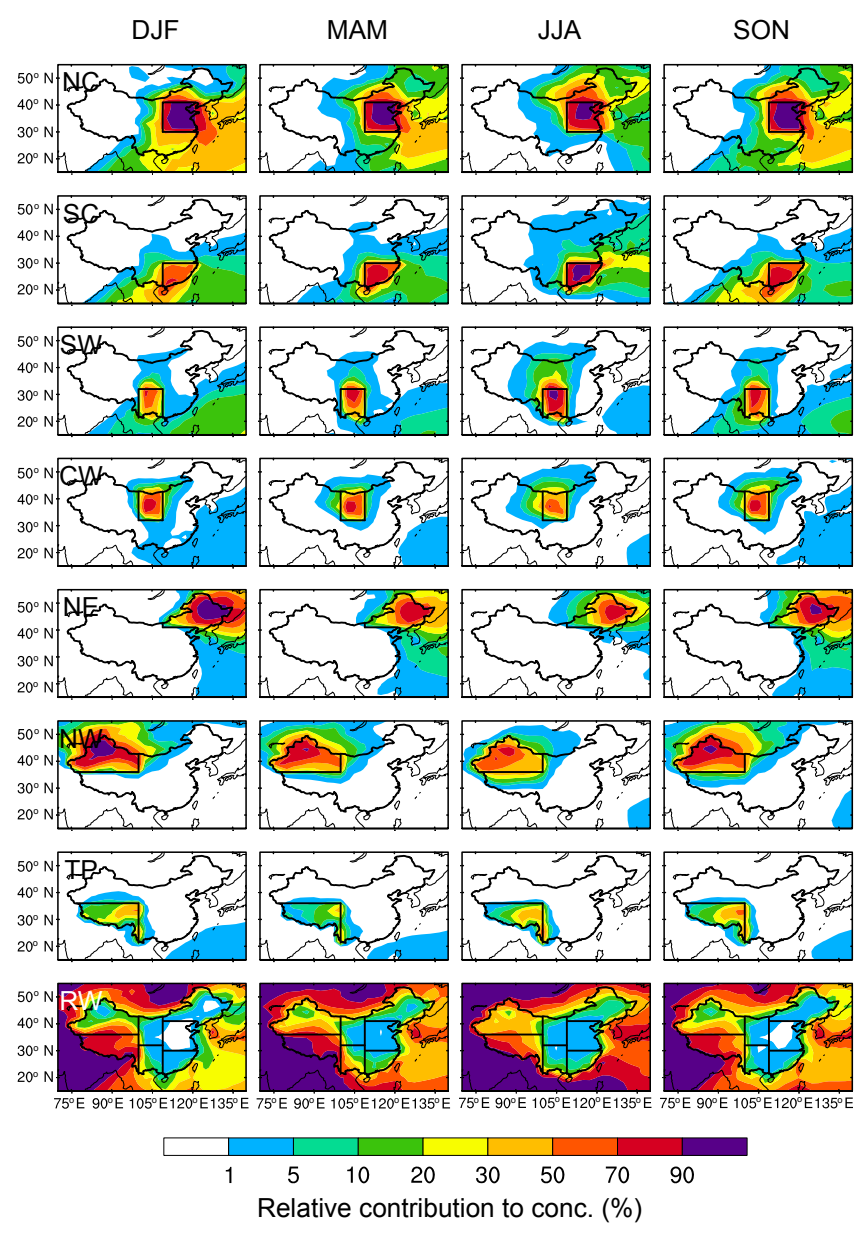

Figure 6. Spatial distribution of relative contributions (\%) to seasonal mean near-surface $\mathrm{BC}$ concentrations from each of the tagged source regions.

simulated source contributions to column burden of BC are shown in Fig. S4. They present a very similar spatial distribution and seasonal variation to those of near-surface $\mathrm{BC}$ concentrations. However, the emissions from outside China have a larger impact on the average column burden of $\mathrm{BC}$ over China than on surface concentrations, with a magnitude of $0.4 \mathrm{mg} \mathrm{m}^{-2}$ in MAM, which is similar to that from sources in north China.

Figure 6 shows the spatial distribution of simulated relative contributions to near-surface $\mathrm{BC}$ concentrations from sources in the seven regions in continental China and those outside China by season. (The same plots for BC column burden are shown in Fig. S5.) For regions with higher emissions, their BC concentrations are dominated by local emissions. In contrast, $\mathrm{BC}$ levels, especially the column burden of $\mathrm{BC}$, over central and western China with lower emissions are strongly influenced by nonlocal sources. Emissions from outside China can be the largest contributor to $\mathrm{BC}$ over these regions. During DJF, MAM and SON, they contribute more than $70 \%$ to both surface concentrations and the column bur-
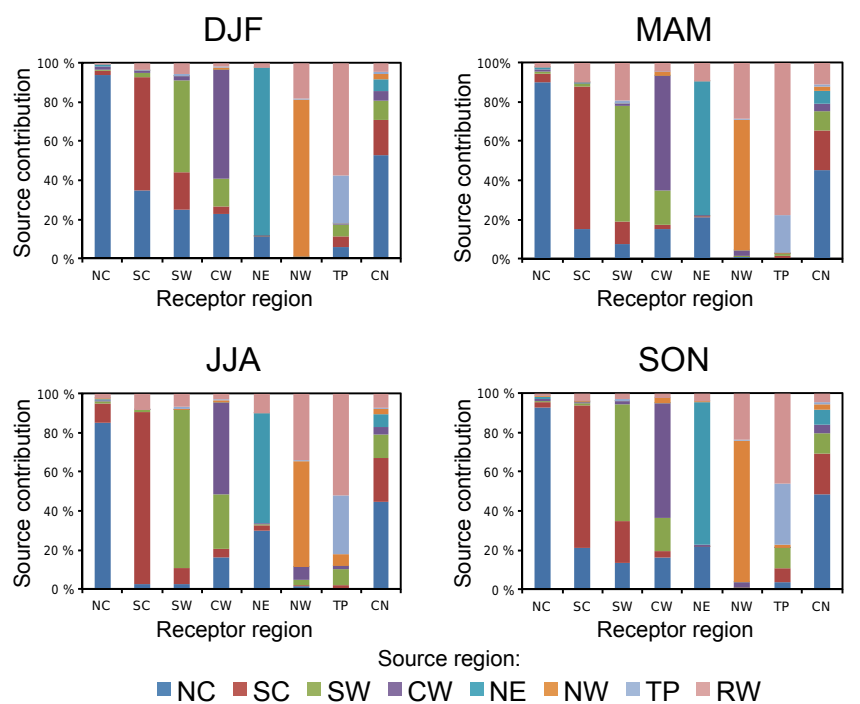

Figure 7. Relative contributions (\%) from the tagged source regions (denoted by colors) to regional mean surface concentrations of $\mathrm{BC}$ over seven receptor regions in China (NC, SC, SW, CW, NE, NW and $\mathrm{TP}$ ) and China (seven regions combined, $\mathrm{CN}$ ) in different seasons. The receptor regions are marked on the horizontal axis in each panel.

den of BC in the Tibetan Plateau, which is important for climate change due to the large climate efficacy of $\mathrm{BC}$ in snow (Qian et al., 2011) and the acceleration of snowmelt through the elevated BC heat pump mechanism (Lau et al., 2010). $\mathrm{BC}$ emissions from outside China also account for a quite significant fraction of surface concentrations over northwest and southwest China in MAM, which contributes to poor air quality over these regions.

Figure 7 summarizes source attribution for spatially averaged seasonal surface $\mathrm{BC}$ concentrations for the seven receptor regions and continental China combined $(\mathrm{CN})$. Over north China, the majority of the $\mathrm{BC}$ concentrations is attributed to local emissions in all seasons, with seasonal fractional contributions of $85-94 \%$. Over south China, the seasonal contributions from local emissions are in the range of 58-88\%. Emissions from north China account for $35 \%$ of BC concentrations over south China in DJF, resulting from the wintertime northwesterly winds (Fig. S6a), while emissions from outside China contribute about $10 \%$ in MAM due to the strong springtime emissions over South and Southeast Asia and southwesterly winds transporting BC from South and Southeast Asia to south China (Fig. S6b). Southwest China has a similar level of local influence, with $47-81 \%$ of the BC concentration from local emissions, whereas $19 \%$ are due to emissions from outside China transported by westerly winds in MAM.

Nonlocal emissions from southwest and north China together contribute $32-44 \%$ of BC concentration in centralwest China. North China emissions play an important role in 

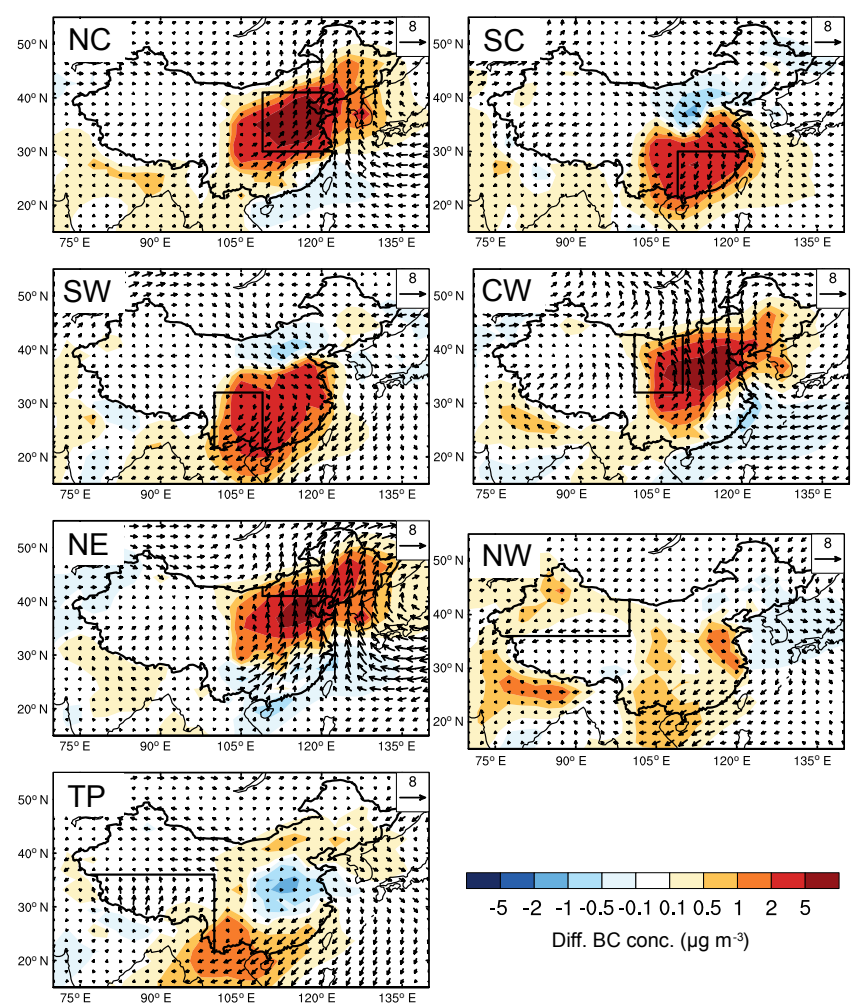

Figure 8. Composite differences in winds at $850 \mathrm{hPa}\left(\mathrm{m} \mathrm{s}^{-1}\right)$ and near-surface $\mathrm{BC}$ concentrations $\left(\mu \mathrm{g} \mathrm{m}^{-3}\right)$ between polluted and normal days in DJF.

$\mathrm{BC}$ concentrations over northeast China, with relative contributions in a range of $21-30 \%$ in MAM, JJA and SON but only $11 \%$ in DJF, which is associated with northwesterly winds in winter preventing northward transport of $\mathrm{BC}$ from north China to northeast China. Over northwest China and the Tibetan Plateau, 18-34 and 46-78\%, respectively, of $\mathrm{BC}$ originate from emissions outside China due to the low emissions over the less economically developed west of China. For all of continental China as the receptor, the seasonal $\mathrm{BC}$ concentrations are largely attributed to the emissions from north and south China, with relative contributions ranging from 44 to 53 and 18 to $22 \%$, respectively, followed by contributions from southwest China (10-12\%) and outside China (5-11\%).

The source region contributions to the column burden of $\mathrm{BC}$ in each receptor region in China are shown in Fig. S7. In general, impacts on the nonlocal $\mathrm{BC}$ column burden are larger than on surface concentrations because aerosol transport is relatively easier in the free troposphere than in the boundary layer (e.g., Yang et al., 2015). Column burdens of $\mathrm{BC}$ averaged over continental China mainly originate from emissions in north China, south China and outside China, with relative contributions ranging from 35-46, 14-21 and $12-30 \%$, respectively.

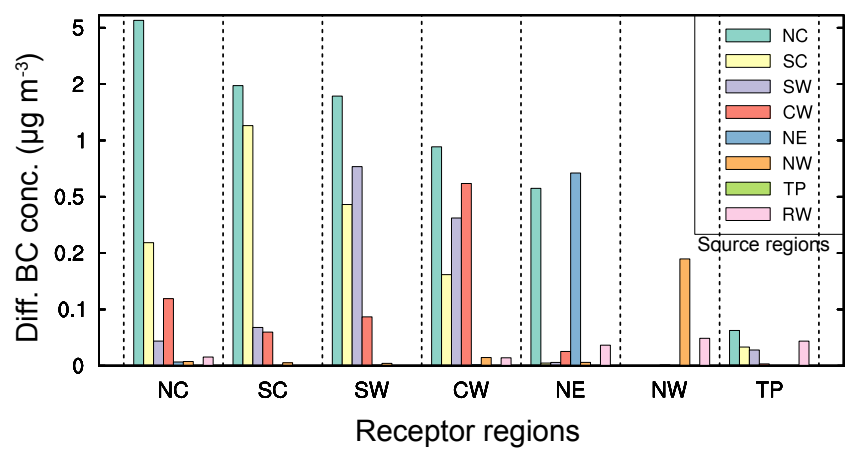

Figure 9. Composite differences in surface $\mathrm{BC}$ concentrations $\left(\mu \mathrm{g} \mathrm{m}^{-3}\right)$ averaged over receptor regions (marked on the horizontal axis) over eastern and central China between polluted and normal days in DJF originating from individual source regions (bars in each column).

\subsection{Source contributions during polluted days}

Knowing the source attribution of $\mathrm{BC}$ during polluted days in China is important for policy makers, which could provide an effective way for the mitigation of poor air quality. Here, the polluted days are simply identified as days with daily concentrations of $\mathrm{BC}$ higher than the 90th percentile of the probability density function in each receptor region. A total of 45 days in winter in the 5-year simulation are identified as polluted days for each region in China.

Figure 8 shows the DJF composite differences in nearsurface BC concentrations and winds at $850 \mathrm{hPa}$ between polluted and normal days for each receptor region, and Fig. 9 summarizes the local and nonlocal source contributions to the differences. When north China is under the polluted condition, $\mathrm{BC}$ concentrations are higher by more than $70 \%$ compared to the DJF average over north China, with a maximum increase exceeding $5 \mu \mathrm{g} \mathrm{m}^{-3}$. North China local emissions contribute $5.6 \mu \mathrm{g} \mathrm{m}^{-3}$ to the averaged increase in BC concentrations over north China during north China polluted days, i.e., about $90 \%$ of the total increase. In winter, eastern China is dominated by strong northwesterly winds (Fig. S6a). The anomalous southerly winds during polluted days (relative to the DJF average) over north China prevent the high $\mathrm{BC}$ concentrations from being transported to south China, leading to a reduced ventilation and to accumulated aerosols in north China.

Over south China, BC concentrations increase by up to 2$5 \mu \mathrm{g} \mathrm{m}^{-3}$, in part due to the transport from north China by anomalous northerly winds in the north part of south China on south China polluted days. On average, the contribution of north China emissions to mean concentrations over south China increases by $2.0 \mathrm{\mu g} \mathrm{m}^{-3}$ ( $60 \%$ of total increase) during the south China polluted days.

During polluted days in southwest China, the anomalous northeasterly winds in the east part of southwest China bring in $\mathrm{BC}$ from highly polluted eastern China, resulting in a 
$2.1 \mu \mathrm{g} \mathrm{m}^{-3}$ increase (74\% of total increase) in southwest China, which is much larger than the $0.7 \mu \mathrm{g} \mathrm{m}^{-3}$ contribution from the southwest China local emissions.

The increase in $\mathrm{BC}$ concentrations during polluted days over central-west China is also largely influenced by the accumulation effect of the anomalous winds over eastern and central China, which also transport BC from southwest and eastern China into the receptor region.

The polluted days in northeast China are caused by both the accumulation of local emissions due to the reduced prevailing northeasterly winds and the anomalous transport of $\mathrm{BC}$ from north China.

Emissions from outside China could contribute to increases in $\mathrm{BC}$ concentrations over northwest China and the Tibetan Plateau during polluted days. However, during wintertime regional polluted days in eastern and central China, the contributions of emissions from outside China do not have a significant influence on the changes in BC concentrations.

These results suggest that the transport of aerosols plays an important role in increasing BC concentrations during regional polluted days in eastern and central China. Reductions in local emissions could benefit the mitigation of both local and nonlocal haze in China. Emissions from outside China are not as important to hazy pollution in eastern and central China, where haze episodes occur frequently in winter due to relatively high anthropogenic aerosol emissions and abnormal meteorological conditions (Sun et al., 2014; R. H. Zhang et al., 2014; Yang et al., 2016). Note that, in this study, we only focus on the source-receptor relationships related to the wind anomalies during polluted days. In addition to winds, changes in other meteorological fields, such as precipitation, temperature, humidity and planetary boundary layer height, could also influence the contributions of local aerosols between polluted and normal days. Although the BC emissions used in the simulation include a seasonal variability that could cause some variations in simulated concentrations, the monthly variability in DJF of BC emissions is less than $4 \%$ over China, which is negligible compared to the differences in concentrations between polluted and normal days.

\subsection{Source contributions to trans-boundary and trans-Pacific transport}

Considering the large contributions of emissions from South and Southeast Asia to MAM BC concentrations in southwest China (Fig. 6) and the large outflow of aerosols from East Asia in springtime (Yu et al., 2008), it is valuable to examine the inflow and outflow of BC in China. Figure S8a and $\mathrm{b}$ show the vertical distribution of source contributions of emissions from outside China to BC concentrations averaged over $75-120^{\circ} \mathrm{E}$ and $25-35^{\circ} \mathrm{N}$, respectively, around the south border of continental China in MAM. High concentrations of BC originating from South and Southeast Asia are lifted to the free atmosphere in the south slope of the Tibetan
Plateau. Then westerly winds transport these BC particles to southwest China and south China in both the low and the mid-troposphere. Figure S8c and d present the contributions of emissions from China to $\mathrm{BC}$ concentrations averaged over $120-135^{\circ} \mathrm{E}$ and $20-50^{\circ} \mathrm{N}$, respectively, around the east border of continental China. In MAM, the northward meridional winds over $25-35^{\circ} \mathrm{N}$ and the southward meridional winds over $40-50^{\circ} \mathrm{N}$ lead to the accumulation of $\mathrm{BC}$ in the lower atmosphere in eastern China. Westerly winds then transport these BC out of China, mostly under $500 \mathrm{hPa}$.

Figure 10 shows the spatial distribution of column burden and surface concentrations of $\mathrm{BC}$ resulting from emissions in and outside China in MAM. Column burden is used to represent the outflow in this study following previous studies (Chin et al., 2007; Hadley et al., 2007). There are strong outflows across the Pacific Ocean originating from emissions both in and outside China. Emissions from China contribute $0.20 \mathrm{mg} \mathrm{m}^{-2}$ (or $55 \%$ ) of MAM mean BC along $150^{\circ} \mathrm{E}$ averaged over $20-60^{\circ} \mathrm{N}$, whereas emissions outside China contribute $0.16 \mathrm{mg} \mathrm{m}^{-2}$ (or $45 \%$ ). It suggests that emissions from both China and outside China are important for the outflow from East Asia. The yearly contribution from emissions from China to outflow from East Asia in this study is 59\%, similar to the contribution of $61 \%$ in Matsui et al. (2013) calculated based on eastward BC mass flux using the WRFCMAQ model with INTEX-B missions. Averaged over the western United States $\left(125-105^{\circ} \mathrm{W}, 30-50^{\circ} \mathrm{N}\right)$, emissions from China account for $8 \%$ of near-surface BC concentrations and $29 \%$ in column burden in MAM, indicating that emissions from China could have a significant impact on air quality in the western United States. More than half of China's contribution to BC over the western United States originates from eastern China (i.e., the tagged north and south China).

\subsection{Source contributions to direct radiative forcing}

The high concentrations of $\mathrm{BC}$ in China could also have a significant impact on the climate system through atmospheric heating or direct radiative forcing. As shown in Fig. 11, the annual mean direct radiative forcing (DRF) of BC at TOA is as high as $3-5 \mathrm{~W} \mathrm{~m}^{-2}$ at some locations. Similar to the source attributions of BC concentrations (Fig. 5) and burden (Fig. S4), regional sources contribute the most to DRF over the respective local regions. Among all the source regions in China, emissions from north, south and southwest China contribute the most to local DRF of $\mathrm{BC}$, with a maximum DRF in the range of $3-5,2-3$ and $3-5 \mathrm{~W} \mathrm{~m}^{-2}$, respectively. Other source regions in China have relatively low contributions, with maximum values less than $2 \mathrm{~W} \mathrm{~m}^{-2}$. Emissions outside China lead to $1-2 \mathrm{~W} \mathrm{~m}^{-2}$ of DRF of BC over south, southwest and northwest China and the Tibetan Plateau and $0.2-1 \mathrm{~W} \mathrm{~m}^{-2}$ over other parts of China, an effect that is quite widespread. 
(a) MAM mean $\mathrm{BC}$ burden (CN)

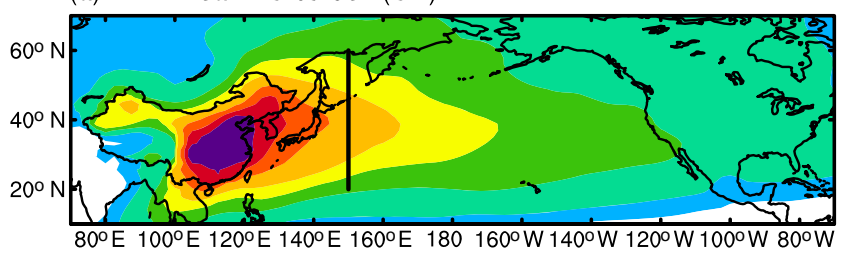

(b) MAM mean $\mathrm{BC}$ burden (RW)
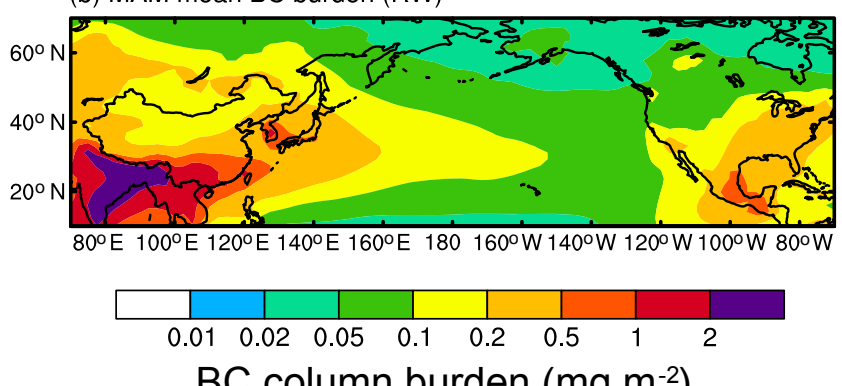

\section{$\mathrm{BC}$ column burden $\left(\mathrm{mg} \mathrm{m}^{-2}\right)$}

(c) MAM mean BC conc. (CN)

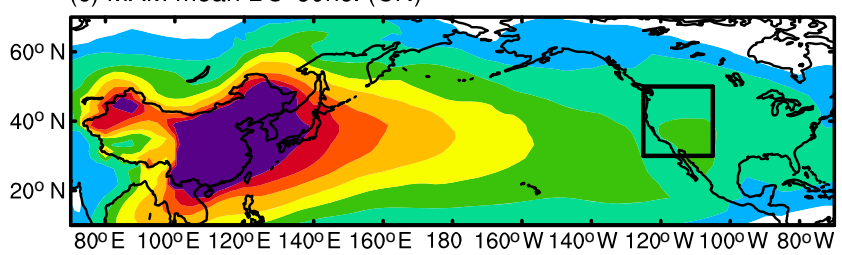

(d) MAM mean BC conc. (RW)
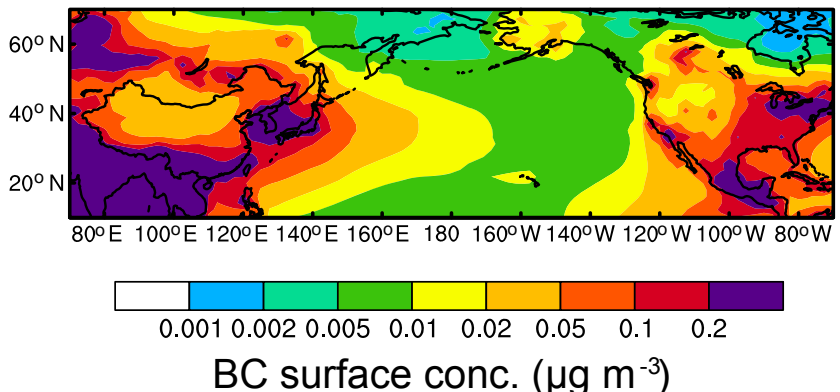

Figure 10. Spatial distribution of $(\mathbf{a}, \mathbf{b})$ column burden $\left(\mathrm{mg} \mathrm{m}^{-2}\right)$ and $(\mathbf{c}, \mathbf{d})$ near-surface concentrations $\left(\mu \mathrm{g} \mathrm{m}^{-3}\right)$ of $\mathrm{BC}$ originating from total emissions inside (CN) and outside China (RW) in MarchApril-May (MAM). The black solid lines over the western $\left(150^{\circ} \mathrm{E}\right.$, $20-60^{\circ} \mathrm{N}$ ) Pacific in panel (a) mark the cross-sections used to quantify outflow of BC from East Asia. The box over the western United States $\left(125-105^{\circ} \mathrm{W}, 30-50^{\circ} \mathrm{N}\right)$ in panel (c) is used to quantify BC concentrations attributed to sources from China.

The total DRF of BC averaged over continental China simulated in this study is $2.20 \mathrm{~W} \mathrm{~m}^{-2}$, larger than 0.64 $1.55 \mathrm{~W} \mathrm{~m}^{-2}$ in previous studies (Wu et al., 2008; Zhuang et al., 2011; Li et al., 2016), probably due to the different emissions in the time periods of study, as shown in Table S5. Emissions outside China have the largest contributions to DRF of BC in China compared to any of the individual source regions in China, with an averaged contribution of $0.78 \mathrm{~W} \mathrm{~m}^{-2}(35 \%)$. This fractional contribution from emis-
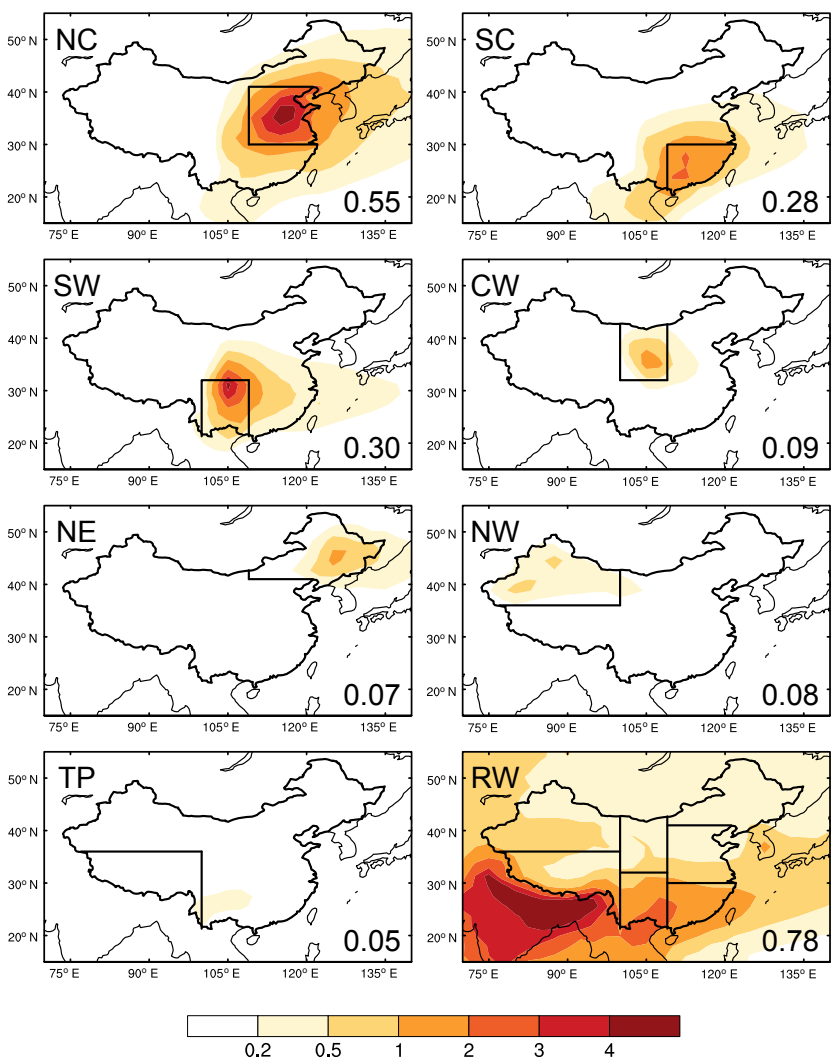

Direct radiative forcing of $\mathrm{BC}\left(\mathrm{W} \mathrm{m}^{-2}\right)$

Figure 11. Spatial distribution of annual mean direct radiative forcing of $\mathrm{BC}\left(\mathrm{W} \mathrm{m}^{-2}\right)$ at the top of the atmosphere originating from the tagged $\mathrm{BC}$ source regions in China (NC, SC, SW, CW, NE, NW and TP) and sources outside China (RW). The regionally averaged forcing in China contributed by individual source regions is shown at the bottom right of each panel.

sions outside China is larger than $25 \%$ in $\mathrm{Li}$ et al. (2016); however, we use different emissions, model and meteorology. Emissions from north China result in $0.55 \mathrm{~W} \mathrm{~m}^{-2}$ ( $25 \%$ ) of DRF of BC over China, followed by $0.30 \mathrm{~W} \mathrm{~m}^{-2}$ $(14 \%)$ and $0.28 \mathrm{~W} \mathrm{~m}^{-2}(13 \%)$ from southwest and south China, respectively. Emissions from central-west, northeast and northwest China and the Tibetan Plateau taken together account for $0.29 \mathrm{~W} \mathrm{~m}^{-2}(13 \%)$ of DRF of BC over China.

Figure 12a shows the seasonal mean DRF of BC averaged over China as a function of regional $\mathrm{BC}$ emissions. Because of high emissions, DRF of $\mathrm{BC}$ emitted from north China is the largest in all seasons, with values in a range of $0.5-$ $0.8 \mathrm{~W} \mathrm{~m}^{-2}$ averaged over China, followed by $0.2-0.5 \mathrm{~W} \mathrm{~m}^{-2}$ from south and southwest China. BC from the other tagged regions in China contributes less than $0.2 \mathrm{~W} \mathrm{~m}^{-2}$ in all seasons. In general, BC DRF in each season is proportional to its emission rate.

Figure $12 \mathrm{~b}$ presents the seasonal DRF efficiencies of BC emitted from the tagged regions and Table S6 summarizes these efficiencies. The variability of DRF efficiencies for 

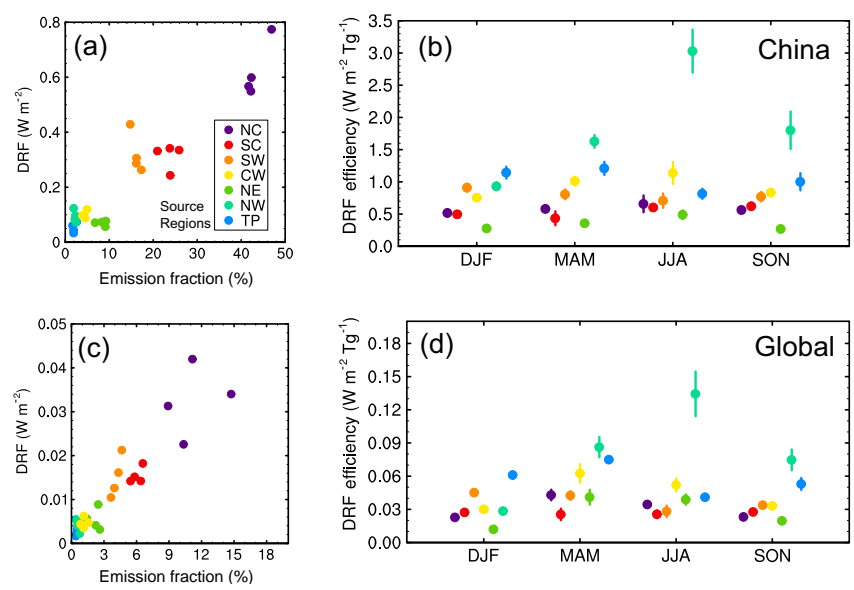

Figure 12. (a, c) BC seasonal DRF averaged over China as a function of $\mathrm{BC}$ emission fraction (the ratio of regional emission to the total emission over China and globally; unit: \%) for each of the tagged regions. (b, d) Seasonal DRF efficiency of $\mathrm{BC}\left(\mathrm{W} \mathrm{m}^{-2} \mathrm{Tg}^{-1}\right)$ for each of the tagged source regions over China and globally, respectively. The efficiency is defined as the DRF divided by the corresponding scaled annual emission (seasonal emission multiplied by 4). Error bars indicate $1 \sigma$ of mean values during 2010-2014.

forcing over China is determined by several factors, such as incoming solar radiation (location of source regions), BC column burden and vertical distribution, and transport out of the region. The China DRF efficiencies are largest in western China (northwest China and the Tibetan Plateau). This spatial pattern was also found by Henze et al. (2012). It can be explained by the increase in multiple scattering effects and the attenuation of the transmitted radiation for large AOD (García et al., 2012). The northeast China region has a low China DRF efficiency due to transport eastward outside of China. The remaining central and southern China regions have China DRF efficiencies that are fairly consistent, varying by $20-30 \%$ of the average. The annual mean and regional mean DRF efficiency from all BC emissions in China is $0.88 \mathrm{~W} \mathrm{~m}^{-2} \mathrm{Tg}^{-1}$, within the range of $0.41-$ $1.55 \mathrm{~W} \mathrm{~m}^{-2} \mathrm{Tg}^{-1}$ from the previous studies (Table S5).

DRF efficiencies of $\mathrm{BC}$ from most regions have higher values in JJA and lower values in DJF. This is primarily due to more incoming solar radiation in summer. Insolation is the largest over northwest China in JJA, together with less precipitation than other regions, resulting in large DRF efficiency there. Global BC DRF efficiencies from tagged regions, particularly the annual average, are fairly similar for central, southern and eastern China regions (Fig. 12c, d). Global efficiencies are still much higher for the western regions.

$\mathrm{BC}$ emission reductions may impact the mitigation of climate change and improve air quality. To compare the relative importance of climate and air quality effects of $\mathrm{BC}$ from different regions in China, Fig. 13 shows the near-surface concentration and column burden efficiencies of $\mathrm{BC}$ over
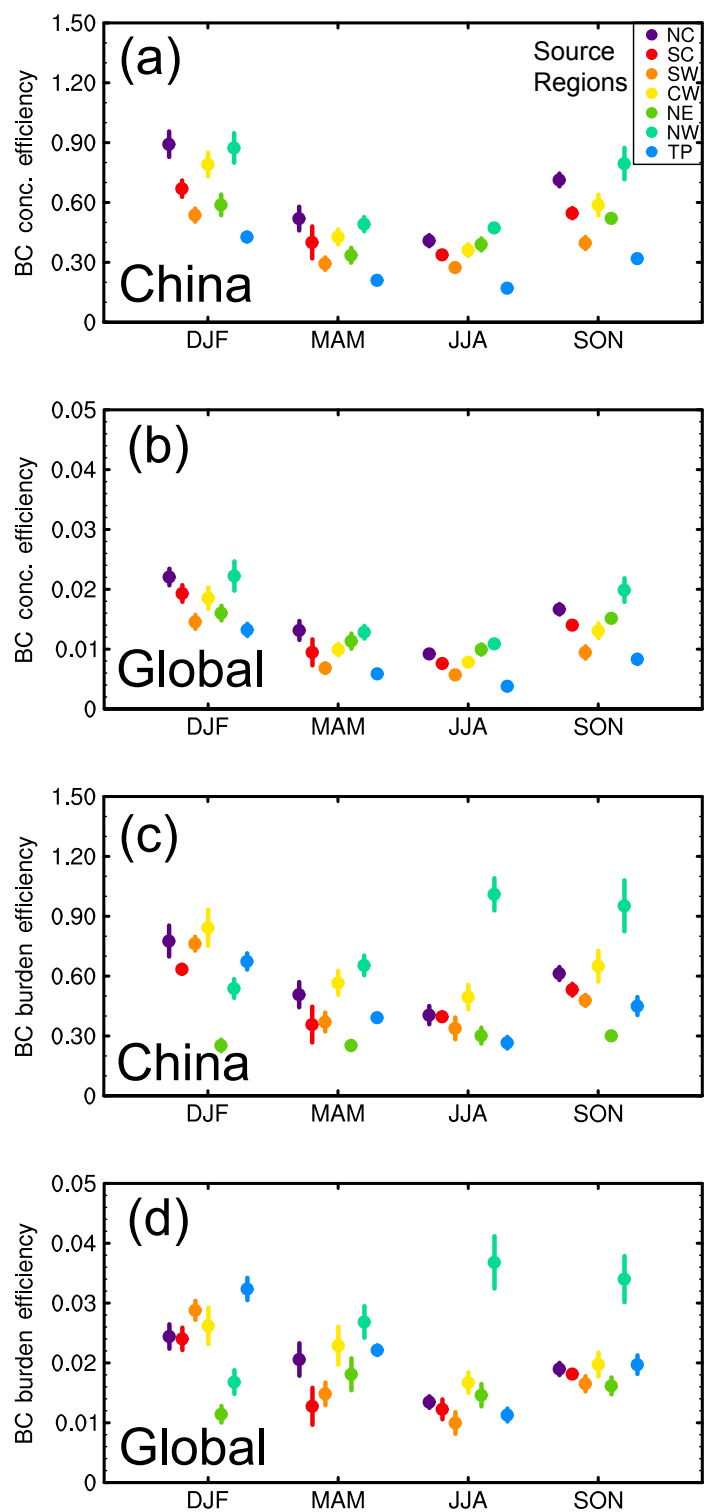

Figure 13. Seasonal (a, b) near-surface concentration $\left(\mu \mathrm{g} \mathrm{m}^{-3} \mathrm{Tg}^{-1}\right)$ and $(\mathbf{c}, \mathbf{d})$ column burden $\left(\mathrm{mg} \mathrm{m}^{-2} \mathrm{Tg}^{-1}\right)$ efficiency of $\mathrm{BC}$ for each of the tagged source regions over China and globally.

China and globally from each tagged region and Table S7 summarizes these efficiencies. For near-surface concentration (Fig. 13a and b), the efficiencies are largest in DJF and lowest in JJA, in contrast to the DRF efficiencies, resulting from less precipitation and wet deposition of aerosols in winter. Unlike the DRF efficiencies, the near-surface concentration efficiencies over eastern China are similar and even larger than those for central and western China. These results suggest that a reduction in $\mathrm{BC}$ emissions in eastern China could have a greater benefit for the regional air quality in China, especially in the winter haze season. 
The relative distributions of column burden efficiencies (Fig. 13c and d) are similar to the DRF efficiencies for the major emitting regions in China, indicating that aerosol lifetime in atmosphere drives DRF, which influences regional and global climate. The western regions (northwest China and the Tibetan Plateau), as expected, have a higher forcing per unit column burden.

\section{Conclusions and discussions}

In this study, the Community Earth System Model (CESM) with a source-tagging technique is used to quantify the contributions of BC emitted from seven regions in continental China, including north China (NC), south China (SC), southwest China (SW), central-west China (CW), northeast China (NE), northwest China (NW) and the Tibetan Plateau (TP), and sources outside China (RW) to concentrations, haze formation, trans-boundary and trans-Pacific transport, and direct radiative forcing (DRF) of $\mathrm{BC}$ in China. The anthropogenic emissions of BC for 2010-2014 used in this study were developed for the Coupled Model Intercomparison Project Phase 6 (CMIP6) from the Community Emissions Data System (CEDS). The annual total emission of BC from continental China is $2497 \mathrm{Gg} \mathrm{C}$ averaged over 2010-2014. The model captures the spatial distribution and seasonal variation in China well. AAOD compares well with measurements, which are largely located in central and eastern China. Surface $\mathrm{BC}$ concentrations are underestimated by $48 \%$ compared to point observations.

The individual source regions are the largest contributors to their local BC concentration levels. Over north China where the air quality is often poor, about $90 \%$ of near-surface $\mathrm{BC}$ concentration is contributed by local emissions. However, some source regions also impact $\mathrm{BC}$ in neighboring regions. Due to the seasonal variability of winds and emission rates, emissions from north China account for $35 \%$ of near-surface BC concentrations over south China in DJF (December-January-February), while emissions from outside China contribute about $10 \%$ in MAM (March-AprilMay). Over southwest China, $19 \%$ of BC in MAM comes from sources outside China. Southwest and north China emissions contribute largely to $\mathrm{BC}$ in central-west China. North China emissions have a contribution in a range of 21$30 \%$ to BC concentrations in northeast China. Over northwest China and the Tibetan Plateau, more than 20 and $40 \%$ of BC, respectively, originates from emissions outside China. These indicate that, for regions with high emissions, their $\mathrm{BC}$ concentrations are dominated by local emissions. In contrast, BC levels over central and western China with lower emissions are more strongly influenced by nonlocal emissions. For continental China as a whole, seasonal BC concentrations are largely due to emissions from north and south China, with relative contributions ranging from 44 to 53 and 18 to $22 \%$, respectively, followed by contributions from southwest (10-12\%) and outside China (5-11\%).

Emissions from nonlocal sources together with abnormal winds are one of the important factors contributing to high winter time pollution events in China. Over south China, about $60 \%$ of the increase in BC concentrations during high pollution conditions results from north China emissions. The increases in $\mathrm{BC}$ concentrations during polluted days over southwest, central-west and northeast China are strongly influenced by emissions from eastern China. Emissions from outside China could contribute significantly to increases in BC concentrations over northwest China and the Tibetan Plateau during their polluted days. However, emissions from outside China do not have a significant contribution to haze in eastern and central China, suggesting that a reduction in emissions within China would be needed to mitigate both local and nonlocal BC concentrations under highly polluted conditions.

Emissions from regions in and outside China both account for about half of BC outflow from East Asia, suggesting that emissions from China and other regions are equally important for the BC outflow from East Asia. Through long-range transport, emissions from China result in $8 \%$ of near-surface BC concentration and $29 \%$ in column burden over the western United States in MAM, indicating that emissions from China could have an impact on air quality in the western United States.

The total DRF of BC averaged over continental China simulated in this study is $2.20 \mathrm{~W} \mathrm{~m}^{-2}$. Among the tagged regions, emissions outside China have the largest single contribution to DRF of BC in China, with an average contribution of $35 \%$, followed by 25,14 and $13 \%$ due to emissions from north, south and southwest China, respectively. DRF efficiencies from eastern China are small compared to central and western China in all seasons. For near-surface concentration, the efficiencies are largest in DJF and lowest in JJA, and efficiencies from eastern China are similar and even larger than in central and western China. These suggest that a reduction in $\mathrm{BC}$ emissions over eastern China could have a greater benefit for the regional air quality in China, especially in the winter haze season.

Note that the model largely underestimates BC concentrations over China, compared to the observation, which has also been reported in many previous studies using different models and different emission inventories (e.g., Liu et al., 2012; Fu et al., 2012; Huang et al., 2013; H. Wang et al., 2013; Q. Wang et al., 2014; R. Wang et al., 2014; Li et al., 2016). One possible reason is that in situ measurements are point observations, while the model does not treat the subgrid variability of aerosols and assumes that aerosols are uniformly distributed over the grid cell. R. Wang et al. (2014) found a reduction in negative bias (from -88 to $-35 \%$ ) in the modeled surface BC concentrations when using highresolution emissions and modeling at $0.5^{\circ} \times 0.7^{\circ}$ resolution. They found, however, that modeling over the North China 
Plain at an even higher resolution of $0.1^{\circ}$ further reduced the surface concentration bias there from 29 to $8 \%$. This result indicates that the siting of observational stations can result in an artificial bias in comparisons with relatively coarse model results. Further investigation of this siting or resolution bias is warranted, including investigation into whether this type of bias might extend, presumably to a lesser extent, also to AAOD measurements.

Further factors that could contribute to this bias are emission underestimation or inaccurate aerosol processes in the model. Given that the differences between modeled and observed AAOD over eastern China are relatively small $(-6 \%)$, we conclude that, given current evidence, the total amount of atmospheric $\mathrm{BC}$ in these simulations is reasonable at least in this subregion.

Over eastern China, the $\mathrm{BC}$ concentrations are dominated by local emissions in this study, with a local contribution of $58-94 \%$. The underestimation of simulated BC concentrations over eastern China is more likely due to either underestimation of local emissions, too much aerosol removal within these regions, or resolution bias between observations and model grids. Over western China, $18-78 \%$ of the BC originates from emissions outside China. Thus biases of simulated BC concentrations could also come from the underestimation of emissions outside China and/or too much removal of BC during long-range transport. Satellite data are a promising method to validate modeling and emissions inventories, given that they do not depend on the location of observing stations, providing more uniform spatial coverage. A comparison of modeled AAOD and satellite AI provides an indication that the modeled burden in western China is underestimated, although the role of dust needs to be better characterized.

Uncertainty in China BC emissions has been estimated as -43 to $93 \%$ by Lu et al. (2011), -50 to $164 \%$ by Qin and Xie (2012), $\pm 176 \%$ by Kurokawa et al. (2013), and -28 to $126 \%$ by Zhao et al. (2013). The BC emissions estimates used here for China in 2010 are $40 \%$ higher than those of Zhao et al. (2013) and Lu et al. (2011) and $30 \%$ higher than Klimont et al. (2016), in large part due to a higher estimate of $\mathrm{BC}$ emissions from coal coke production. Emissions from coke production are particularly uncertain given that "there are no measurements for $\mathrm{PM}_{2.5}$ and $\mathrm{BC}$ emissions" (Huo et al., 2012) available to guide inventory estimates. The total rest of the world emissions other than China, which appear to be a major contributor to burdens over western regions, are within $1 \%$ of those from Klimont et al. (2016).

$\mathrm{BC}$ aging in the atmosphere is important for $\mathrm{BC}$ concentration and its optical properties, which transforms BC from hydrophobic aggregates to hydrophilic particles coated with soluble materials (Cheng et al., 2006). He et al. (2015, 2016a) found that $\mathrm{BC}$ optical properties varied by a factor of 2 or more due to different coating structures during the $\mathrm{BC}$ aging process based on their theoretical and experimental intercomparison. Oshima et al. (2009) and He et al. (2016b) pointed out that the use of various microphysical $\mathrm{BC}$ aging schemes could significantly improve simulations of BC concentrations, compared to the simplified aging parameterizations. Liu et al. (2012) also reported that the wet removal rate of BC simulated in standard CAM5 is $60 \%$ higher than the AeroCom multi-model mean due to the rapid or instantaneous aging of BC. H. Wang et al. (2013) showed that the explicit treatment of the $\mathrm{BC}$ aging process with slow aging assumptions in CAM5 could significantly increase BC lifetime and the efficiency of $\mathrm{BC}$ long-range transport. In the three-mode aerosol module (MAM3) of CAM5 used in this study, the aging process of $\mathrm{BC}$ is neglected by assuming the immediate internal mixing of $\mathrm{BC}$ with other aerosol species in the same mode. This assumption could lead to an overestimation of wet removal of $\mathrm{BC}$ and, therefore, an underestimation of BC concentrations, absorption optical depth (Fig. 3) and direct radiative forcing. In addition, the internally mixed optical treatment in CAM5 could also cause bias in BC absorption calculation. However, H. Wang et al. (2014) examined source-receptor relationships for $\mathrm{BC}$ under the different $\mathrm{BC}$ aging assumptions and found that the quantitative source attributions varied slightly while the qualitative source-receptor relationships still hold. Therefore, although the magnitude of simulated $\mathrm{BC}$ and its optical properties could be underestimated due to the instantaneous aging of $\mathrm{BC}$ and uncertainty in coating structures, we expect that the aging treatment in MAM3 of CAM5 should not influence the qualitative source attributions examined in this study.

In this study, BC is used as an indicator of pollution (or air quality) in China. Although BC is often co-emitted with other species, such as primary organic matter, organic gases and sulfuric gases, the source-receptor relationship of BC may not fully represent that of total aerosols. The contribution of $\mathrm{BC}$ to total near-surface $\mathrm{PM}_{2.5}$ concentrations averaged over China is less than $10 \%$. Other aerosols, such as sulfate, are dominant in China during polluted days. The spatiotemporal variations and source contributions of these species are largely different from those of $\mathrm{BC}$ because spatial distributions of emissions (e.g., $\mathrm{SO}_{2}$ ) and formation processes can be considerably different. For example, Matsui et al. (2009) showed that primary aerosols around Beijing were determined by emissions within $100 \mathrm{~km}$ around Beijing within the preceding $24 \mathrm{~h}$, while emissions as far as $500 \mathrm{~km}$ and within the preceding 3 days were found to affect secondary aerosols in Beijing. Thus, the secondary aerosols could have larger contributions from nonlocal emissions than $\mathrm{BC}$. BC concentrations are highest in winter over China due to higher emissions, while sulfate concentrations reach a maximum in summer when strong sunlight and high temperatures favor the sulfate formation. Therefore, knowing the accurate source attributions of air pollution in China requires source tagging for more aerosol species, such as sulfate. 
Data availability. The CESM model can be downloaded from http: //www.cesm.ucar.edu/models/cesm1.2/. All the emissions datasets can be obtained from https://pcmdi.llnl.gov/projects/input4mips. The AERONET AAOD data are available from https://aeronet.gsfc. nasa.gov/cgi-bin/webtool_aod_v3. The satellite-derived aerosol index monthly data can be downloaded from https://disc.sci.gsfc.nasa. gov/data-holdings/PIP/aerosol_index.shtml. Our model results can be made available through the National Energy Research Scientific Computing Center (NERSC) severs upon request.

\section{The Supplement related to this article is available online at doi:10.5194/acp-17-4319-2017-supplement.}

Competing interests. The authors declare that they have no conflict of interest.

Acknowledgements. This research was supported by the National Atmospheric and Space Administration's Atmospheric Composition: Modeling and Analysis Program (ACMAP), award NNH15AZ64I. We also acknowledge additional support from the U.S. Department of Energy (DOE), Office of Science, Biological and Environmental Research. The Pacific Northwest National Laboratory is operated for DOE by Battelle Memorial Institute under contract DE-AC05-76RLO1830. The CESM project was supported by the National Science Foundation and the DOE Office of Science. The National Energy Research Scientific Computing Center (NERSC) provided computational resources. Model results are available through NERSC upon request.

Edited by: H. Su

Reviewed by: three anonymous referees

\section{References}

Abdul-Razzak, H. and Ghan, S. J.: A parameterization of aerosol activation: 2. Multiple aerosol types, J. Geophys. Res., 105, 68376844, doi:10.1029/1999JD901161, 2000.

Anenberg, S. C., Talgo, K., Arunachalam, S., Dolwick, P., Jang, C., and West, J. J.: Impacts of global, regional, and sectoral black carbon emission reductions on surface air quality and human mortality, Atmos. Chem. Phys., 11, 7253-7267, doi:10.5194/acp-11-7253-2011, 2011.

Bond, T. C. and Bergstrom, R. W.: Light absorption by carbonaceous particles: An investigative review, Aerosol. Sci. Tech., 40, 27-67, doi:10.1080/02786820500421521, 2006

Bond, T. C., Bhardwaj, E., Dong, R., Jogani, R., Jung, S., Roden, C., Streets, D. G., and Trautmann, N. M.: Historical emissions of black and organic carbon aerosol from energy-related combustion, 1850-2000, Global Biogeochem. Cy., 21, GB2018, doi:10.1029/2006GB002840, 2007.

Bond, T. C., Doherty, S. J., Fahey, D. W., Forster, P. M., Berntsen, T., DeAngelo,B. J., Flanner, M. G., Ghan, S., Kärcher, B., Koch, D., Kinne, S., Kondo, Y., Quinn, P. K., Sarofim, M. C., Schultz, M. G., Schulz, M., Venkataraman, C., Zhang, H., Zhang, S., Bellouin, N., Guttikunda, S. K., Hopke, P. K., Jacob- son, M. Z., Kaiser, J. W., Klimont, Z., Lohmann, U., Schwarz, J. P., Shindell, D., Storelvmo, T., Warren, S. G., and Zender, C. S.: Bounding the role of black carbon in the climate system: A scientific assessment, J. Geophys. Res., 118, 5380-5552, doi:10.1002/jgrd.50171, 2013.

Cheng, Y. F., Eichler, H., Wiedensohler, A., Heintzenberg, J., Zhang, Y. H., Hu, M., Herrmann, H., Zeng, L. M., Liu, S., Gnauk, T., Bruggemann, E., and He, L. Y.: Mixing state of elemental carbon and non-light-absorbing aerosol components derived from in situ particle optical properties at Xinken in Pearl River Delta of China, J. Geophys. Res.-Atmos., 111, D20204, doi:10.1029/2005JD006929, 2006.

Chin, M., Diehl, T., Ginoux, P., and Malm, W.: Intercontinental transport of pollution and dust aerosols: implications for regional air quality, Atmos. Chem. Phys., 7, 5501-5517, doi:10.5194/acp7-5501-2007, 2007.

Ding, Y. H. and Liu, Y. J.: Analysis of long-term variations of fog and haze in China in recent 50 years and their relations with atmospheric humidity, Sci. China Ser. D, 57, 36-46, doi:10.1007/s11430-013-4792-1, 2014.

Flanner, M. G., Zender, C. S., Randerson, J. T., and Rasch, P. J.: Present day climate forcing and response from black carbon in snow, J. Geophys. Res., 112, D11202, doi:10.1029/2006JD008003, 2007.

Fu, T.-M., Cao, J. J., Zhang, X. Y., Lee, S. C., Zhang, Q., Han, Y. M., Qu, W. J., Han, Z., Zhang, R., Wang, Y. X., Chen, D., and Henze, D. K.: Carbonaceous aerosols in China: top-down constraints on primary sources and estimation of secondary contribution, Atmos. Chem. Phys., 12, 2725-2746, doi:10.5194/acp12-2725-2012, 2012

García, O. E., Díaz, J. P., Expósito, F. J., Díaz, A. M., Dubovik, O., Derimian, Y., Dubuisson, P., and Roger, J.-C.: Shortwave radiative forcing and efficiency of key aerosol types using AERONET data, Atmos. Chem. Phys., 12, 5129-5145, doi:10.5194/acp-12 5129-2012, 2012.

Ghan, S. J.: Technical Note: Estimating aerosol effects on cloud radiative forcing, Atmos. Chem. Phys., 13, 9971-9974, doi:10.5194/acp-13-9971-2013, 2013.

Ghan, S. J. and Zaveri, R. A.: Parameterization of optical properties for hydrated internally mixed aerosol, J. Geophys. Res., 112, D10201, doi:10.1029/2006JD007927, 2007.

Hadley, O. L., Ramanathan, V., Carmichael, G. R., Tang, Y., Corrigan, C. E., Roberts, G. C., and Mauger, G. S.: TransPacific transport of black carbon and fine aerosols $(D<$ $2.5 \mu \mathrm{m})$ into North America, J. Geophys. Res., 112, D05309, doi:10.1029/2006JD007632, 2007.

He, C., Liou, K.-N., Takano, Y., Zhang, R., Levy Zamora, M., Yang, P., Li, Q., and Leung, L. R.: Variation of the radiative properties during black carbon aging: theoretical and experimental intercomparison, Atmos. Chem. Phys., 15, 11967-11980, doi:10.5194/acp-15-11967-2015, 2015.

He, C., Takano, Y., Liou, K.-N., Yang, P., Li, Q., and Mackowski, D. W.: Intercomparison of the GOS approach, superposition Tmatrix method, and laboratory measurements for black carbon optical properties during aging, J. Quant. Spectrosc. Ra., 184, 287-296, doi:10.1016/j.jqsrt.2016.08.004, 2016a.

He, C., Li, Q., Liou, K.-N., Qi, L., Tao, S., and Schwarz, J. P.: Microphysics-based black carbon aging in a global CTM: constraints from HIPPO observations and implications for global 
black carbon budget, Atmos. Chem. Phys., 16, 3077-3098, doi:10.5194/acp-16-3077-2016, 2016 b.

Henze, D. K., Shindell, D. T., Akhtar, F. R., Spurr, J. D., Pinder, R. W., Loughlin, D., Kopacz, M., Singh, K., and Shim, C.: Spatially refined aerosol direct radiative forcing efficiencies, Environ. Sci. Technol., 46, 9511-9518, doi:10.1021/es301993s, 2012.

Hoesly, R. M., Smith, S. J., Feng, L., Klimont, Z., JanssensMaenhout, G., Pitkanen, T., Seibert, J. J., Vu, L., Andres, R. J., Bolt, R. M., Bond, T. C., Dawidowski, L., Kholod, N., Kurokawa, J.-I., Li, M., Liu, L., Lu, Z., Moura, M. C. P., O'Rourke, P. R., and Zhang, Q.: Historical (1750-2014) anthropogenic emissions of reactive gases and aerosols from the Community Emission Data System (CEDS), Geosci. Model Dev. Discuss., doi:10.5194/gmd-2017-43, in review, 2017.

Holben, B. N., Tanré, D., Smirnov, A., Eck, T. F., Slutsker, I., Abuhassan, N., Newcomb, W. W., Schafer, J. S., Chatenet, B., Lavenu, F., Kaufman, Y. J., Castle, J. V., Setzer, A., Markham, B., Frouin, D. C. R., Halthore, R., Karneli, A., O’Neill, N. T., Pietras, C., Pinker, R. T., Voss, K., and Zibordi, G.: An emerging ground-based aerosol climatology: Aerosol optical depth from AERONET, J. Geophys. Res., 106, 12067-12098, 2001.

Huang, Y., Wu, S., Dubey, M. K., and French, N. H. F.: Impact of aging mechanism on model simulated carbonaceous aerosols, Atmos. Chem. Phys., 13, 6329-6343, doi:10.5194/acp-13-63292013, 2013.

Huo, H., Lei, Y., Zhang, Q., Zhao, L. J., and He, K. B.: China's coke industry: Recent policies, technology shift, and implication for energy and the environment, Energ. Policy, 51, 397-404, doi:10.1016/j.enpol.2012.08.041, 2012.

Hurrell, J. W., Holland, M. M., Gent, P. R., Ghan, S., Kay, J. E., Kushner, P. J., Lamarque, J. F., Large, W. G., Lawrence, D., Lindsay, K., Lipscomb, W. H., Long, M. C., Mahowald, N., Marsh, D. R., Neale, R. B., Rasch, P., Vavrus, S., Vertenstein, M., Bader, D., Collins, W. D., Hack, J. J., Kiehl, J., and Marshall, S.: The Community Earth System Model A Framework for Collaborative Research, B. Am. Meteorol. Soc., 94, 1339-1360, 2013.

IPCC: Climate Change 2013: the Physical Science Basis. Contribution of Working Group I to the Fifth Assessment Report of the Intergovernmental Panel on Climate Change, Cambridge University Press, Cambridge, United Kingdom and New York, NY, USA, 1535 pp., 2013.

Jacobson, M. Z.: Effects of externally-through-internally-mixed soot inclusions within clouds and precipitation on global climate, J. Phys. Chem. A, 110, 6860-6873, doi:10.1021/Jp056391r, 2006.

Janssen, N. A. H., Gerlofs-Nijiland, M. E., Lanki, T., Salonen, R. O., Cassee, F., Hoek, G., Fischer, P., Brunekreef, B., and Krzyzanowski, M.: Health Effects of Black Carbon, World Health Organization, Copenhagen, 2012.

Janssens-Maenhout, G., Crippa, M., Guizzardi, D., Dentener, F., Muntean, M., Pouliot, G., Keating, T., Zhang, Q., Kurokawa, J., Wankmüller, R., Denier van der Gon, H., Kuenen, J. J. P., Klimont, Z., Frost, G., Darras, S., Koffi, B., and Li, M.: HTAP_v2.2: a mosaic of regional and global emission grid maps for 2008 and 2010 to study hemispheric transport of air pollution, Atmos. Chem. Phys., 15, 11411-11432, doi:10.5194/acp15-11411-2015, 2015.

Jiao, C., Flanner, M. G., Balkanski, Y., Bauer, S. E., Bellouin, N., Berntsen, T. K., Bian, H., Carslaw, K. S., Chin, M., De Luca, N.,
Diehl, T., Ghan, S. J., Iversen, T., Kirkevåg, A., Koch, D., Liu, X., Mann, G. W., Penner, J. E., Pitari, G., Schulz, M., Seland, Ø., Skeie, R. B., Steenrod, S. D., Stier, P., Takemura, T., Tsigaridis, K., van Noije, T., Yun, Y., and Zhang, K.: An AeroCom assessment of black carbon in Arctic snow and sea ice, Atmos. Chem. Phys., 14, 2399-2417, doi:10.5194/acp-14-2399-2014, 2014.

Klimont, Z., Kupiainen, K., Heyes, C., Purohit, P., Cofala, J., Rafaj, P., Borken-Kleefeld, J., and Schöpp, W.: Global anthropogenic emissions of particulate matter including black carbon, Atmos. Chem. Phys. Discuss., doi:10.5194/acp-2016-880, in review, 2016.

Koepke, M. H. P. and Schult, I.: Optical properties of aerosols and clouds: The software package opac, B. Am. Meteorol. Soc., 79, 831-844, doi:10.1175/15200477(1998)079<0831:OPOAAC>2.0.CO;2, 1998.

Kristiansen, N. I., Stohl, A., Olivié, D. J. L., Croft, B., Søvde, O. A., Klein, H., Christoudias, T., Kunkel, D., Leadbetter, S. J., Lee, Y. H., Zhang, K., Tsigaridis, K., Bergman, T., Evangeliou, N., Wang, H., Ma, P.-L., Easter, R. C., Rasch, P. J., Liu, X., Pitari, G., Di Genova, G., Zhao, S. Y., Balkanski, Y., Bauer, S. E., Faluvegi, G. S., Kokkola, H., Martin, R. V., Pierce, J. R., Schulz, M., Shindell, D., Tost, H., and Zhang, H.: Evaluation of observed and modelled aerosol lifetimes using radioactive tracers of opportunity and an ensemble of 19 global models, Atmos. Chem. Phys., 16, 3525-3561, doi:10.5194/acp-16-3525-2016, 2016.

Kurokawa, J., Ohara, T., Morikawa, T., Hanayama, S., JanssensMaenhout, G., Fukui, T., Kawashima, K., and Akimoto, H.: Emissions of air pollutants and greenhouse gases over Asian regions during 2000-2008: Regional Emission inventory in ASia (REAS) version 2, Atmos. Chem. Phys., 13, 11019-11058, doi:10.5194/acp-13-11019-2013, 2013.

Lau, K.-M., Kim, M. K., Kim, K.-M., and Lee, W. S.: Enhanced surface warming and accelerated snow melt in the Himalayas and Tibetan Plateau induced by absorbing aerosols, Environ. Res. Lett., 5, 025204, doi:10.1088/1748-9326/5/2/025204, 2010.

Li, K., Liao, H., Mao, Y. H., and Ridley, D. A.: Source sector and region contributions to concentration and direct radiative forcing of black carbon in China, Atmos. Environ., 124, 351-366, doi:10.1016/j.atmosenv.2015.06.014, 2016.

Liao, H., Chang, W. Y., and Yang, Y.: Climatic effects of air pollutants over China: A review, Adv. Atmos. Sci., 32, 115-139, doi:10.1007/s00376-014-0013-x, 2015.

Liu, X., Easter, R. C., Ghan, S. J., Zaveri, R., Rasch, P., Shi, X., Lamarque, J.-F., Gettelman, A., Morrison, H., Vitt, F., Conley, A., Park, S., Neale, R., Hannay, C., Ekman, A. M. L., Hess, P., Mahowald, N., Collins, W., Iacono, M. J., Bretherton, C. S., Flanner, M. G., and Mitchell, D.: Toward a minimal representation of aerosols in climate models: description and evaluation in the Community Atmosphere Model CAM5, Geosci. Model Dev., 5, 709-739, doi:10.5194/gmd-5-709-2012, 2012.

Liu, X., Ma, P.-L., Wang, H., Tilmes, S., Singh, B., Easter, R. C., Ghan, S. J., and Rasch, P. J.: Description and evaluation of a new four-mode version of the Modal Aerosol Module (MAM4) within version 5.3 of the Community Atmosphere Model, Geosci. Model Dev., 9, 505-522, doi:10.5194/gmd-9505-2016, 2016.

Lou, S., Russell, L. M., Yang, Y., Xu, L., Lamjiri, M. A., DeFlorio, M. J., Miller, A. J., Ghan, S. J., Liu, Y., and Singh, B.: Impacts of the East Asian Monsoon on springtime dust concen- 
trations over China, J. Geophys. Res.-Atmos., 121, 8137-8152, doi:10.1002/2016JD024758, 2016.

Lu, Z., Zhang, Q., and Streets, D. G.: Sulfur dioxide and primary carbonaceous aerosol emissions in China and India, 1996-2010, Atmos. Chem. Phys., 11, 9839-9864, doi:10.5194/acp-11-98392011, 2011.

Ma, P.-L., Gattiker, J. R., Liu, X., and Rasch, P. J.: A novel approach for determining source-receptor relationships in model simulations: a case study of black carbon transport in northern hemisphere winter, Environ. Res. Lett., 8, 024042, doi:10.1088/17489326/8/2/024042, 2013a.

Ma, P.-L., Rasch, P. J., Wang, H., Zhang, K., Easter, R. C., Tilmes, S., Fast, J. D., Liu, X., Yoon, J.-H., and Lamarque, J.-F.: The role of circulation features on black carbon transport into the Arctic in the Community Atmosphere Model version 5 (CAM5), J. Geophys. Res.-Atmos., 118, 4657-4669, doi:10.1002/jgrd.50411, 2013b.

Matsui, H., Koike, M., Kondo, Y., Takegawa, N., Kita, K., Miyazaki, Y., Hu, M., Chang, S.-Y., Blake, D. R., Fast, J. D., Zaveri, R. A., Streets, D. G., Zhang, Q., and Zhu, T.: Spatial and temporal variations of aerosols around Beijing in summer 2006: Model evaluation and source apportionment, J. Geophys. Res., 114, D00G13, doi:10.1029/2008JD010906, 2009.

Matsui, H., Koike, M., Kondo, Y., Oshima, N., Moteki, N., Kanaya, Y., Takami, A., and Irwin, M.: Seasonal variations of Asian black carbon outflow to the Pacific: Contribution from anthropogenic sources in China and biomass burning sources in Siberia and Southeast Asia, J. Geophys. Res.-Atmos., 118, 9948-9967, doi:10.1002/jgrd.50702, 2013.

McFarquhar, G. and Wang, H.: Effects of aerosols on trade wind cumuli over the Indian Ocean: Model simulations, Q. J. Roy. Meteor. Soc., 132, 821-843, doi:10.1256/qj.04.179, 2006.

Oshima, N., Koike, M., Zhang, Y., Kondo, Y., Moteki, N., Takegawa, N., and Miyazaki, Y.: Aging of black carbon in outflow from anthropogenic sources using a mixing state resolved model: Model development and evaluation, J. Geophys. Res., 114, D06210, doi:10.1029/2008JD010680, 2009.

Oshima, N., Kondo, Y., Moteki, N., Takegawa, N., Koike, M., Kita, K., Matsui, H., Kajino, M., Nakamura, H., Jung, J. S., and Kim, Y. J.: Wet removal of black carbon in Asian outflow: Aerosol Radiative Forcing in East Asia (A-FORCE) aircraft campaign, J. Geophys. Res., 117, D03204, doi:10.1029/2011jd016552, 2012.

Qian, Y., Flanner, M. G., Leung, L. R., and Wang, W.: Sensitivity studies on the impacts of Tibetan Plateau snowpack pollution on the Asian hydrological cycle and monsoon climate, Atmos. Chem. Phys., 11, 1929-1948, doi:10.5194/acp-11-19292011, 2011.

Qian, Y., Wang, H., Zhang, R., Flanner, M. G., and Rasch, P. J.: A sensitivity study on modeling black carbon in snow and its radiative forcing over the Arctic and Northern China, Environ. Res. Lett., 9, 064001, doi:10.1088/1748-9326/9/6/064001, 2014.

Qian, Y., Yasunari, T. J., Doherty, S. J., Flanner, M. G., Lau, W. K. M., Ming, J., Wang, H., Wang, M., Warren, S. G., and Zhang, R.: Light-absorbing particles in snow and ice: Measurement and modeling of climatic and hydrological impact, Adv. Atmos. Sci., 32, 64-91, doi:10.1007/s00376-014-0010-0, 2015.

Qin, Y. and Xie, S. D.: Spatial and temporal variation of anthropogenic black carbon emissions in China for the period 1980-
2009, Atmos. Chem. Phys., 12, 4825-4841, doi:10.5194/acp-124825-2012, 2012.

Ramanathan, V. and Carmichael, G.: Global and regional climate changes due to black carbon, Nat. Geosci., 1, 221-227, doi:10.1038/ngeo156, 2008.

Rienecker, M. M., Suarez, M. J., Gelaro, R., Todling, R., Bacmeister, J., Liu, R., Bosilovich, M. G., Schubert, S. D., Takacs, L., Kim, G-K, Bloom, S., Chen, J., Collins, D., Conaty, A., da Silva, A., Gu, W., Joiner, J., Koster, R. D., Lucchesi, R., Molod, A., Owens, T., Pawson, S., Pegion, P., Redder, C. R., Reichle, R., Robertson, F. R., Ruddick, A. G., Sienkiewicz, M., and Woollen, J.: MERRA: NASA's Modern-Era Retrospective Analysis for Research and Applications, J. Climate, 24, 3624-3648, 2011.

Schuster, G. L., Dubovik, O., Arola, A., Eck, T. F., and Holben, B. N.: Remote sensing of soot carbon - Part 2: Understanding the absorption Ångström exponent, Atmos. Chem. Phys., 16, 15871602, doi:10.5194/acp-16-1587-2016, 2016.

Shindell, D., Kuylenstierna, J. C. I., Vignati, E., van Dingenen, R., Amann, M., Klimont, Z., Anenberg, S. C., Muller, N., Janssens- Maenhout, G., Raes, F., Schwartz, J., Faluvegi, G., Pozzoli, L., Kupiainen, K., Höglund-Isaksson, L., Emberson, L., Streets, D., Ramanathan, V., Hicks, K., Oanh, N. T. K., Milly, G., Williams, M., Demkine, V., and Fowler, D.: Simultaneously Mitigating Near-Term Climate Change and Improving Human Health and Food Security, Science, 335, 183-189, doi:10.1126/science.1210026, 2012.

Smith, S. J. and Mizrahi, A.: Near-term climate mitigation by short-lived forcers, P. Natl. Acad. Sci. USA, 110, 14202-14206, doi:10.1073/pnas.1308470110, 2013.

Sun, Y., Jiang, Q., Wang, Z., Fu, P., Li, J., Yang, T., and Yin, Y.: Investigation of the sources and evolution processes of severe haze pollution in Beijing in January 2013, J. Geophys. Res.-Atmos., 119, 4380-4398, doi:10.1002/2014JD021641, 2014.

van Marle, M. J. E., Kloster, S., Magi, B. I., Marlon, J. R., Daniau, A.-L., Field, R. D., Arneth, A., Forrest, M., Hantson, S., Kehrwald, N. M., Knorr, W., Lasslop, G., Li, F., Mangeon, S., Yue, C., Kaiser, J. W., and van der Werf, G. R.: Historic global biomass burning emissions based on merging satellite observations with proxies and fire models (1750-2015), Geosci. Model Dev. Discuss., doi:10.5194/gmd-2017-32, in review, 2017.

Wang, H., Easter, R. C., Rasch, P. J., Wang, M., Liu, X., Ghan, S. J., Qian, Y., Yoon, J.-H., Ma, P.-L., and Vinoj, V.: Sensitivity of remote aerosol distributions to representation of cloud-aerosol interactions in a global climate model, Geosci. Model Dev., 6, 765-782, doi:10.5194/gmd-6-765-2013, 2013.

Wang, H., Rasch, P. J., Easter, R. C., Singh, B., Zhang, R., Ma, P.-L., Qian, Y., Ghan, S. J., and Beagley, N.: Using an explicit emission tagging method in global modeling of source-receptor relationships for black carbon in the Arctic: Variations, sources, and transport pathways, J. Geophys. Res.-Atmos., 119, 12888 12909, doi:10.1002/2014JD022297, 2014.

Wang, L. T., Wei, Z., Yang, J., Zhang, Y., Zhang, F. F., Su, J., Meng, C. C., and Zhang, Q.: The 2013 severe haze over southern Hebei, China: model evaluation, source apportionment, and policy implications, Atmos. Chem. Phys., 14, 3151-3173, doi:10.5194/acp-14-3151-2014, 2014.

Wang, M., Ghan, S., Ovchinnikov, M., Liu, X., Easter, R., Kassianov, E., Qian, Y., and Morrison, H.: Aerosol indirect effects in 
a multi-scale aerosol-climate model PNNL-MMF, Atmos. Chem. Phys., 11, 5431-5455, doi:10.5194/acp-11-5431-2011, 2011.

Wang, Q., Jacob, D. J., Spackman, J. R., Perring, A. E., Schwarz, J. P., Moteki, N., Marais, E. A., Ge, C., Wang, J., and Barrett, S. R. H.: Global budget and radiative forcing of black carbon aerosol: Constraints from pole-to-pole (HIPPO) observations across the Pacific, J. Geophys. Res.-Atmos., 119, 195-206, doi:10.1002/2013jd020824, 2014.

Wang, R., Tao, S., Balkanski, Y., Ciais, P., Boucher, O., Liu, J., Piao, S., Shen, H., Vuolo, M. R., and Valari, M.: Exposure to ambient black carbon derived from a unique inventory and high- resolution model, P. Natl. Acad. Sci. USA, 111, 2459-2463, 2014.

Wang, X., Wang, Y., Hao, J., Kondo, Y., Irwin, M., Munger, J. W., and Zhao, Y.: Top-down estimate of China's black carbon emissions using surface observations: Sensitivity to observation representativeness and transport model error, J. Geophys. Res.Atmos., 118, 5781-5795, doi:10.1002/jgrd.50397, 2013.

Wu, J., Fu, C., Xu, Y., Tang, J. P., Wang, W., and Wang, Z.: Simulation of direct effects of black carbon aerosol on temperature and hydrological cycle in Asia by a Regional Climate Model, Meteorol. Atmos. Phys., 100, 179-193, doi:10.1007/s00703-008-0302y, 2008.

Yang, Y., Liao, H., and Lou, S.: Decadal trend and interannual variation of outflow of aerosols from East Asia: Roles of variations in meteorological parameters and emissions, Atmos. Environ., 100, 141-153, doi:10.1016/j.atmosenv.2014.11.004, 2015.

Yang, Y., Liao, H., and Lou, S.: Increase in winter haze over eastern China in recent decades: Roles of variations in meteorological parameters and anthropogenic emissions, J. Geophys. Res.Atmos., 121, 13050-13065, doi:10.1002/2016JD025136, 2016.

Yu, H., Remer, L. A., Chin, M., Bian, H., Kleidman, R. G., and Diehl, T.: A satellite-based assessment of transpacific transport of pollution aerosol, J. Geophys. Res., 113, D14S12, doi:10.1029/2007JD009349, 2008.

Zhang, K., Wan, H., Liu, X., Ghan, S. J., Kooperman, G. J., Ma, P.-L., Rasch, P. J., Neubauer, D., and Lohmann, U.: Technical Note: On the use of nudging for aerosol-climate model intercomparison studies, Atmos. Chem. Phys., 14, 8631-8645, doi:10.5194/acp-14-8631-2014, 2014.

Zhang, L. M., Gong, S. L., Padro, J., and Barrie, L.: A size-segregated particle dry deposition scheme for an atmospheric aerosol module, Atmos. Environ., 35, 549-560, doi:10.1016/S1352-2310(00)00326-5, 2001.

Zhang, Q., Streets, D. G., Carmichael, G. R., He, K. B., Huo, H., Kannari, A., Klimont, Z., Park, I. S., Reddy, S., Fu, J. S., Chen, D., Duan, L., Lei, Y., Wang, L. T., and Yao, Z. L.: Asian emissions in 2006 for the NASA INTEX-B mission, Atmos. Chem. Phys., 9, 5131-5153, doi:10.5194/acp-9-5131-2009, 2009.

Zhang, R., Wang, H., Hegg, D. A., Qian, Y., Doherty, S. J., Dang, C., Ma, P.-L., Rasch, P. J., and Fu, Q.: Quantifying sources of black carbon in western North America using observationally based analysis and an emission tagging technique in the Community Atmosphere Model, Atmos. Chem. Phys., 15, 12805-12822, doi:10.5194/acp-15-12805-2015, 2015a.
Zhang, R., Wang, H., Qian, Y., Rasch, P. J., Easter, R. C., Ma, P.L., Singh, B., Huang, J., and Fu, Q.: Quantifying sources, transport, deposition, and radiative forcing of black carbon over the Himalayas and Tibetan Plateau, Atmos. Chem. Phys., 15, 62056223, doi:10.5194/acp-15-6205-2015, 2015b.

Zhang, R. H., Li, Q., and Zhang, R. N.: Meteorological conditions for the persistent severe fog and haze event over eastern China in January 2013, Sci. China Earth Sci., 57, 26-35, doi:10.1007/s11430-013-4774-3, 2014.

Zhang, X. Y., Wang, Y. Q., Zhang, X. C., Guo, W., and Gong, S. L.: Carbonaceous aerosol composition over various regions of China during 2006, J. Geophys. Res., 113, D14111, doi:10.1029/2007JD009525, 2008.

Zhang, X. Y., Wang, Y. Q., Niu, T., Zhang, X. C., Gong, S. L., Zhang, Y. M., and Sun, J. Y.: Atmospheric aerosol compositions in China: spatial/temporal variability, chemical signature, regional haze distribution and comparisons with global aerosols, Atmos. Chem. Phys., 12, 779-799, doi:10.5194/acp12-779-2012, 2012.

Zhang, Y.-L., Huang, R.-J., El Haddad, I., Ho, K.-F., Cao, J.-J., Han, Y., Zotter, P., Bozzetti, C., Daellenbach, K. R., Canonaco, F., Slowik, J. G., Salazar, G., Schwikowski, M., Schnelle-Kreis, J., Abbaszade, G., Zimmermann, R., Baltensperger, U., Prévôt, A. S. H., and Szidat, S.: Fossil vs. non-fossil sources of fine carbonaceous aerosols in four Chinese cities during the extreme winter haze episode of 2013, Atmos. Chem. Phys., 15, 1299-1312, doi:10.5194/acp-15-1299-2015, 2015.

Zhao, Y., Zhang, J., and Nielsen, C. P.: The effects of recent control policies on trends in emissions of anthropogenic atmospheric pollutants and $\mathrm{CO}_{2}$ in China, Atmos. Chem. Phys., 13, 487-508, doi:10.5194/acp-13-487-2013, 2013.

Zhuang, B. L., Jiang, F., Wang, T. J., Li, S., and Zhu, B.: Investigation on the direct radiative effect of fossil fuel blackcarbon aerosol over China, Theor. Appl. Climatol., 104, 301312, doi:10.1007/s00704-010-0341-4, 2011.

Zhuang, B. L., Liu, Q., Wang, T. J., Yin, C. Q., Li, S., Xie, M., Jiang, F., and Mao, H. T.: Investigation on semi-direct and indirect climate effects of fossil fuel black carbon aerosol over China, Theor. Appl. Climatol., 114, 651-672, doi:10.1007/s00704-0130862-8, 2013.

Zhuang, B. L., Wang, T. J., Liu, J., Li, S., Xie, M., Yang, X. Q., Fu, C. B., Sun, J. N., Yin, C. Q., Liao, J. B., Zhu, J. L., and Zhang, Y.: Continuous measurement of black carbon aerosol in urban Nanjing of Yangtze River Delta, China, Atmos. Environ., 89, 415-424, doi:10.1016/j.atmosenv.2014.02.052, 2014. 